\title{
Geleneksel Türk Evi ile Geleneksel Japon Evi’nin Yapısal Açıdan Karşılaştırılması
}

\author{
Uğur Özcan ${ }^{1 *}$, Sena Güngör ${ }^{2}$ \\ ${ }^{1}$ Fatih Sultan Mehmet Vakıf Üniversitesi, Mimarlık ve Tasarım Fakültesi, Mimarlık Bölümü, İstanbul, Türkiye (ORCID: 0000-0003-0002-4478) \\ ${ }^{2}$ Fatih Sultan Mehmet Vakıf Üniversitesi, Lisansüstü Eğitim Enstitüsü, Mimarlık Anabilimdalı, İstanbul, Türkiye (ORCID: 0000-0002-1124-2385)
}

(İlk Geliş Tarihi 1 Temmuz 2019 ve Kabul Tarihi 24 Temmuz 2019)

(DOI: 10.31590/ejosat.591305)

ATIF/REFERENCE: Özcan, U. \& Güngör, S. (2019). Geleneksel Türk Evi ile Geleneksel Japon Evi'nin Yapısal Açıdan Karşılaştırılması. Avrupa Bilim ve Teknoloji Dergisi, (16), 646-661.

$\ddot{\mathbf{O z}}$

Tarih öncesi dönemlerden günümüze dek barınma, insanoğlunun temel yaşamsal gereksinimleri arasında yer almıştır. Toplumsal gelişim sürecinde, barınma kavramına bakış açısının değişmesi, mimari üretimde farklılıklara neden olmuş ve yeni yaşam koşullarına cevap verebilecek mekân kurgusuna sahip konutlar geliştirilmiştir. Toplumun tarihi kent kimliğinin imleyicisi olan geleneksel konut mimarisi, toplumsal yapı, kültürel değerler, sosyal eğilimler, inanç sistemleri ve tarihsel birikim ile paralel olarak biçimlenerek toplumsal, sosyal, kültürel ve tarihsel boyutlarıyla dinamik bir olgu haline gelmektedir. Farklı coğrafyalarda, farklı toplumlarda üretilen geleneksel konutlar, toplumun ortak kültürel mirasının ürünü olması, tarihi belleğini oluşturması ve yaşam felsefesini yansıtması bakımından önemli bir misyon üstlenmektedir. Kültürel değerlerini muhafaza etmeyi başarmış iki toplumun ideolojik tutumları, kültürel dinamikleri, sosyal eğilimleri, inanç sistemleri, ekonomik yapısı, teknolojik düzeyi ve toplumun yaşanmışlıkları ile biçimlenen, geleneksel tasarım ilkelerinin vücud bulduğu geleneksel Türk Evi ile Japon Evi yüzlerce yıldır varlığını sürdürmektedir. $\mathrm{Bu}$ çalışmada, iki farklı toplumda üretilen geleneksel konut mimarisinde uygulanan mimari tasarım yaklaşımları arasındaki benzerlikler ve farklılıklar karşılaştırmalı olarak incelenerek iki konut geleneğinin özgün değerini ve önemini ortaya koymak amaçlanmıştır. İki geleneksel konut mimarisi, oluşumundan uygulanan tasarım ilkelerinin ve yapısal özelliklerinin tarihsel, sosyal, kültürel ve ideolojik arka planları tahlil edilerek değerlendirilmiştir. Geleneksel Türk Evi ile Japon Evi'nin oluşumunda etkili olan coğrafi koşullar ve iklimsel özellikler ile birlikte iki toplumun geleneksel yaşamı, değerler yargıları ve kültürel dinamikleri bağlamında iki konut geleneğinin fiziksel ve işlevsel oluşumları, yapısal ve mekânsal özellikleri ile estetiksel zenginlikleri ortaya konulmuştur. Birbirinden farklı iki topluma ait geleneksel konut mimarisi arasında yapılan karşılaştırmalı analiz bulguları değerlendirildiğinde, farklı işlevleri bir arada barındıran esnek mekân kurgusu, iç mekân biçimlenişinde uygulanan detaylar bakımından iki geleneksel konut geleneği oldukça yakın benzerlikler gösterdikleri, özgün yapım teknikleri ve yapısal özellikler, iç mekan organizasyonunda uygulanan ilkeler açısından birbirlerinden farklı nitelikler taşıdıkları anlaşılmaktadır.

\section{The Structural Comparison of the Traditional Turkish House with the Traditional Japanese House}

\begin{abstract}
From prehistoric times to the present day, dwelling has been among the basic vital needs of human beings. In the process of communal development, the change in the perspective of dwelling concept has caused differences in architectural production and
\end{abstract}

${ }^{*}$ Sorumlu Yazar: Fatih Sultan Mehmet Vakıf Üniversitesi, Mimarlık ve Tasarım Fakültesi, Mimarlık Bölümü, İstanbul, Türkiye, ORCID: 0000-00030002-4478, uozcan@fsm.edu.tr 
houses was developed which could meet the new living conditions. The traditional dwelling architecture which is the marker of the urban identity, is shaped in parallel with the social structure, cultural values, social tendencies, belief systems and historical accumulation, becomes a dynamic phenomenon with its communal, social, cultural and historical dimensions. The traditional houses produced in different geographies and different societies undertake an important mission in terms of being the product of the common cultural heritage of the society, forming the historical memory and reflecting the philosophy of lifestyle. The traditional Turkish House and Japanese House, which is shaped by the ideological attitudes, cultural dynamics, social tendencies, belief systems, economic structure, technological level and the experience of the society, has been in existence for hundreds of years. In this study, the similarities and differences between the architectural design approaches applied in traditional dwelling architectures, which are produced in two different communities, were examined comparatively and it was aimed to reveal the original value and importance of the two dwelling traditions. Two traditional dwelling architecture have been evaluated by analyzing the historical, social, cultural and ideological backgrounds of design principles and structural features applied in their formation. The geographical conditions and climatic features with the physical and functional formations, structural and spatial features and aesthetic richness that influenced the formation of the traditional Turkish House and the Japanese House were revealed in the context of the traditional life, values judgments and cultural dynamics. When the findings of the comparative analysis between two traditional dwelling architectures are evaluated, it is understood that the two dwelling traditions show similarities in terms of the flexible spatial configuration and the interior design details and differences in terms of the principles applied in the interior organization, construction techniques and structural features.

Keywords: Traditional Dwelling Architecture, Traditional Turkish House, Traditional Japanese House.

\section{Giriş}

Konut ve yerleşmenin tarihi, avcılık ve toplayıcılık yapan toplumun, hava koşullarından ve olumsuz çevresel etkenlerden korunmak, yaşamlarını sürdürebilmek için sığındıkları mağara, kovuk gibi doğal barınaklar ile başlamakta, yerleşik yaşam düzenine geçilmesiyle insanın kendi çabalarıyla yapmış olduğu ilkel konutlar ile devam etmektedir. Gelişen teknolojik düzey, toplumsal gelişmenin getirdiği yeni yaşam biçimleri, işlevsel örgütlenme, değişen ihtiyaç ve isteklere bağlı olarak konut mimarisi, uzun bir gelişim ve değişim sürecinden geçmiştir.

“İnsan en eski dönemden başlayarak sığınma, barınma gereksinimi duymuş, kimi zaman bunu mağara, kaya sığınağı, kovuk gibi doğadaki hazır biçimlerle karşılamış, kimi zaman da kendisi geçici diğer çözümler üretmiştir. Bu dönem boyunca, taşlardan basit örüler, dal, kamış ya da hayvan kemiklerinden üstleri deriyle kaplı çadır-sepet türü barınaklar yapmış, kimi zaman da barınağını korunaklı duruma getirmek için toprağa çukur kazmıştır.” (Özdoğan, 1996)
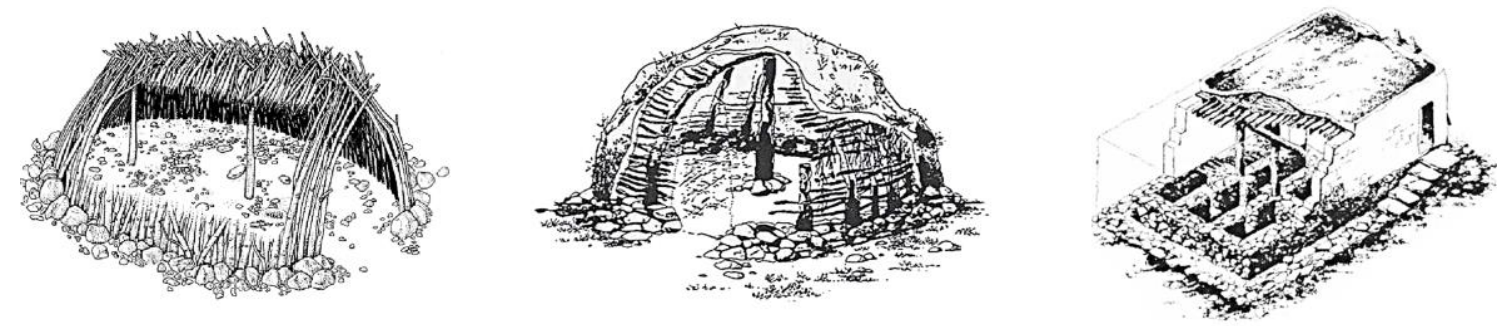

Şekil 1. Ilkel barınak tipleri (URL-1;URL-2)

“İlk Üretim Çağı” olarak adlandırılan Neolitik dönemde (M.Ö. 8000-5500) göçebe yaşamdan yerleşik düzene geçilmesi ve üretimin başlamasıyla birlikte kalıcı yaşam alanları kurulmaya başlanmıştır. Bu döneme tarihlenen, Konya ilinin Çumra ilçesinde yer alan Çatalhöyük yerleşmesinde (M.Ö. 7400-5200), "dikdörtgen bir ana oda ve erzak odası görevinde olan bir ya da iki yan oda kesin bir tasardır. Bitişik düzende yapılmış olan evlerin duvarları bağımsızdır. Evlere çatılardaki deliklerden el merdivenleri yoluyla girilmesi, yerleşmenin kapalı bir bütün olmasını sağlamıştır. Evlerin dış yüzeylerinin oluşturduğu kapalı yüzey savunma duvarı yerine geçiyordu, bu nedenle ayrıca özel bir savunma duvarının yapımı gerekmemiştir.” (Naumann, 2007)

Geleneksel Japon Evi, basit strüktürleri, farklı yapısal bileşenleri ve özgün iç mekân elemanları ile dinamik, zengin ve karakteristik bir mimari tasarıma sahiptir. Geleneksel Japon konut mimarisinin tarihsel gelişim süreci içinde, toplum ve geleneksel konut mimarisi bütünlüğüne dayalı historiyografik kurgu, yerleşik yaşam düzenine geçildiği yerleşim alanlarında inşa edilen ilkel barınaklardan gelişmiş plan kurgusuna sahip konutlara kadar uzanan bir gelişim süreci geçirmiştir.

Uzun bir tarihsel oluşum ve gelişim sürecinden geçmiş; toplumun yaşam biçimi, kültürel değerleri ve inanç sistemleri bütününden oluşan toplumsal dinamikler ile oluşturulan geleneksel konut mimarisi, kültürel mirasın önemli bileşenleri arasında yer almaktadır. Bu bağlamda, geniş bir coğrafyada yayılım gösteren ve yoğun bir tarihi birikimden beslenen, kültürel zenginliğin ürünü olan geleneksel Türk Evi ile Japon Evi, farklı strüktürel özellikleri, özgün yapısal bileşenleri ve iç mekân elemanları ile dinamik, zengin ve karakteristik bir mimari tasarıma sahiptirler. 


\section{Geleneksel Türk Evi ve Geleneksel Japon Evi}

\subsection{Geleneksel Türk Evi}

Geleneksel Türk Evi, “Orta Anadolu bozkırı ile Anadolu platosunu çevreleyen dağ silsileleri arasında Orta Anadolu'nun doğusundan Batı Anadolu'ya ve Balkanlar'a uzanan bü yük bir coğrafi bölgede” (Kuban, 2017) oluşmuş ve Türk ailesinin geleneksel yaşam kültürünü yansıtan ve gereksinimlerine cevap veren plan özelliklerine sahip bir konut tipidir. "Anadolu'da, hareketli göçebe kültür geleneğinin izlerini taşıyan hafif ahşap iskelet yapı tekniği ile vücuda getirilen Türk Evi, Osmanlı Devleti'nin geniş sınırları içerisinde yer alan Balkanlar, Kafkaslar, Hazar Bölgesi ve Kırım'ı kapsayan, uygun yapı malzemesinin kolayca temin edilebildiği geniş bir coğrafi alanda yaygın şekilde uygulanmıştır.” (Cansever, 2002)

Kültürel değerlere ve toplumsal özelliklere bağlı kalınarak oluşturulan geleneksel Türk Evi’nin mekân organizasyonunun biçimlenişinde, Türklerin geçmişte sürdükleri yaşam biçimleri ve bu dönemlerde edindikleri mimari deneyimler ile yerleştikleri bölgelerin coğrafi ve iklimsel özellikleri, geleneksel yaşam kültürleri, dini ve tinsel değerler etkili olmuştur.

Orta Asya'da göçebe yaşam sürdüren Türklerin barındıkları göçer çadırının iç mekân kurgusunda sistemleştirilen ilkeler, Anadolu'da yerleşik düzenin benimsenmesinin ardından toplumsal gelişmenin getirdiği yeni yaşam biçimi, değişen üretim biçimi, yeni ihtiyaçlar ve istekler doğrultusunda şekillenerek geleneksel Türk Evi'nin kuruluşunda uygulanmıştır. Gerçekçi bir yaklaşımla akılcı, işlevsel ve esnek çözümlerin uygulandığı mekân organizasyonu ile kurgulanan geleneksel Türk Evi, aile yapısında meydana gelebilecek değişim ihtiyacı doğrultusunda gerektiğinde evin büyümesine veya küçülmesine imkân sağlanmaktadır. Konut tasarımı, içten dişa doğru gelişerek öncelikle işlev çözümlenmiş ve mekânlar insan ölçülerine göre uygun olarak düzenlenmiştir.

Geleneksel Türk Evi'nin planimetrik özellikleri ve mekânlar arasındaki ilişkiler, coğrafi koşullar, topografik ve iklimsel özellikleri kapsayan doğal-fiziksel faktörlerin yanında Türk-İslam aile yapısı, geniş aile düzeni, dini değerler ve kadının aile içindeki, toplumdaki yeri gibi sosyo-kültürel faktörler ile bağlantılı olarak şekillenmektedir.

Cengiz Bektaş (2018), Türk Evi’nin oluşumunda etkili olan ilkeleri şu başlıklar altında sınıflandırmıştır:

- Yaşama, doğaya, çevre koşullarına uygunluk

- Gerçekçilik, usa uyumluluk (akılcılık)

- $\quad$ İçten dişa çözüm

- İç-diş uyuşumu

- Tutumsallik

- Kolaylık

- Ölçülerin insan vücuduna göre oluşturulması

- İklime uygunluk

- Gereçlerin en yakından seçilmesi

- Esneklik

Cengiz Bektaş’a göre (2018), bu ilkeler her zaman çağlarıyla çağdaş olmuşlardır. Üslup, süsleme ve moda akım değişimlerinde dahi bu ilkelerden ödün verilmemiş ve daima uygulanmıştır.

Türk ailesinin geleneksel yaşam biçimine bağlı kalınarak oluşturulan odalar, kendi içinde gündelik yaşama dair (oturma, dinlenme, yemek yeme, uyuma gibi) ihtiyaçları karşılayabilecek niteliklere sahiptir. Mekânlar arasındaki iletişimi ve etkileşimi sağlayan ve gündelik yaşamın büyük bir bölümünün geçtiği, ev halkının toplandığı ve çeşitli etkinliklerin düzenlendiği sofa ise, geleneksel Türk Evi'nin mekânsal organizasyonuna katılmaktadır. Toplumsal değerlere ve kültürel dinamiklere bağlı kalınarak mekânsal özellikleri geliştirilmiş olan geleneksel Türk Evi'nde yaşam katının mekân organizasyonunu oluşturan oda ve sofa, plan tipini belirleyici ana unsurlardır.

Geleneksel Türk Evi'nde uygulanan plan tipleri, odaların sofa ile olan ilişkisine ve sofanın konut içerisindeki konumuna bağlı olarak değişkenlik göstermektedir. Geleneksel Türk Evi plan tiplerinin sınıflandırılmasına ilişkin ilk çalışmayı ortaya koyan Sedad Hakkı Eldem, bu sınıflandırmayı yaparken plan tiplerinin geçirdiği gelişmeleri dikkate almıştır. Sofasız, dış sofalı, iç sofalı ve orta sofalı olmak üzere dört başlık altında topladığı çalışmada, en basit plan tipinden en gelişmiş plan tipine doğru uzanan bir yol izlemiştir.

\section{Geleneksel Türk Evi'nin Yapısal Özellikleri}

Geniş bir coğrafyada yayılım gösteren ve yoğun bir tarihi birikimden beslenen, kültürel zenginliğin ürünü olan geleneksel Türk Evi'nin yapısal elemanları, işlevlerinin ötesinde mekânın zenginleşmesini ve yapının kendine özgü kimliğinin oluşmasını sağlamaktadırlar. İslam dini gereğince, sade ve gösterişsiz bir yaşam biçimini benimseyen Türk toplumunun imleyicisi olan geleneksel Türk Evi'nin mekân kurgusunun oluşumunda yer alan yapısal elemanların biçimlenişinde yalın, net bir üslup takip edilmiş ve bu elemanlar yapıyla bütünleştirilmiştir. 
“Türk Evi'nde, kapı ve pencereler, odaların iç-dış çevre ilişkilerine önemli özellikler getirmişlerdir. Kapı ve pencereler, iç düzenin kuruluşunu güçlü bir biçimde etkilemiştir. Toplumsal inanışlar ve gelenekler, evin kendi içine doğru çekilmesini gerektirmiştir. Ama yine de bazı çözümlerle dış çevreye, sokağa ve yapı dışına açılma eğilimi görülmektedir. Bu eğilim, evin çevresel örgütlenmesinin ilkeleri, giderek kapı ve pencereleri etkilemiştir.” (Küçükerman, 1985)

Geleneksel Türk Evi'nde oda kapıları, genellikle tek kanatlı, genişliği $80 \mathrm{~cm}$ kadar ve yüksekliği ise odanın faydalı kullanım alanının üst sınır seviyesinde oluşturulur. Oda kapılarının açılış yönü, iç mekândaki mahremiyetin korunması ve mekâna girişlerin denetlenmesi için daima oda içine doğru açılacak şekilde tasarlanır. Kapıların odaya bakan yüzeyleri özenle tezyin edilirken sofaya bakan dış yüzeyleri ise yalın bırakılır. Dikdörtgen veya kemer şeklinde ahşap veya taş söveler içine oturan dış kapılar, zemin katın masif cephe yüzeyinde girişi vurgulamakta ve konutun diş dünya ile ilişkisini sağlamaktadır. Türk toplumundaki yaşama, doğaya ve çevre koşullarına karşı sergilenen saygılı tutum göz önünde bulundurularak tasarlanan "kuzulu kapı"nın çift kanatları atlı arabalar için açılırken, bir kanadında insan için küçük, evcil hayvanlar için de küçücük bir başka kanat tasarlanır.
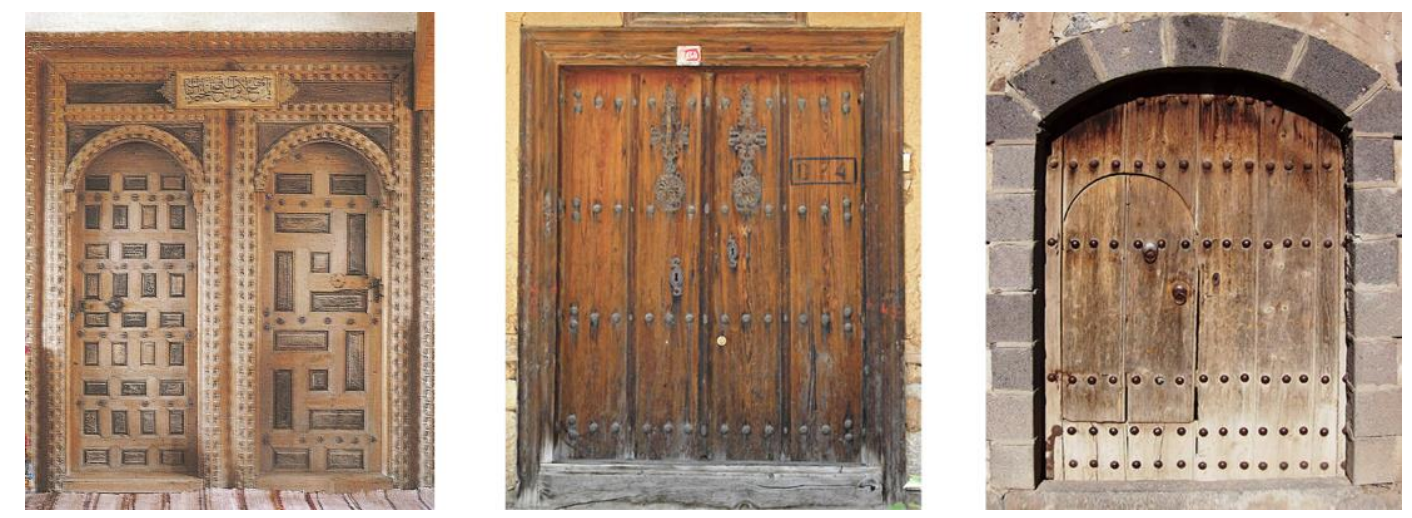

Resim 1. Geleneksel Türk Evi’nde oda kapısı, dı̧s kapı ve kuzulu kapı (Kuban, 1995; URL-3; URL-4)
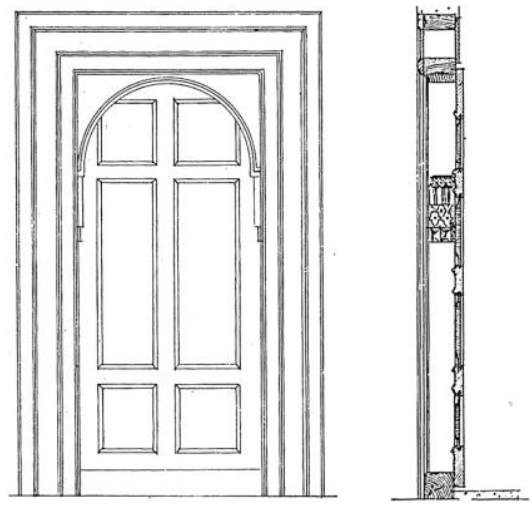

Şekil 2. Oda kaplsı detayları (Akok, 1957)

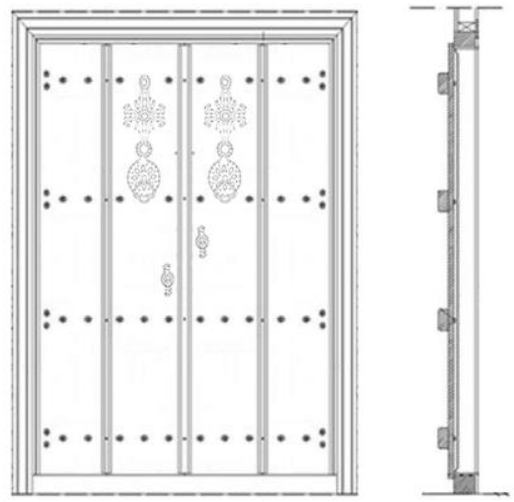

Şekil 3. Dış kapı detayları (Keskin ve Yıldırım, 2016)

Cephe düzenlemelerinde görsel bir etkisi olan kapıların üzerindeki kapı tokmakları, kapı kilitleri ve sövelerde kullanılan renkli taşlar ile konutun giriş bölümü ön plana çıkarılır. Dış kapı üzerindeki her biri farklı sesler çıkaran ve farklı motifleri olan iki kapı tokmakları, mahremiyet olgusu ön plana çıkarılarak tasarlanmış; konuğun kadın ya da erkek olduğunun ayırt edilebilmesi için oluşturulmuştur.

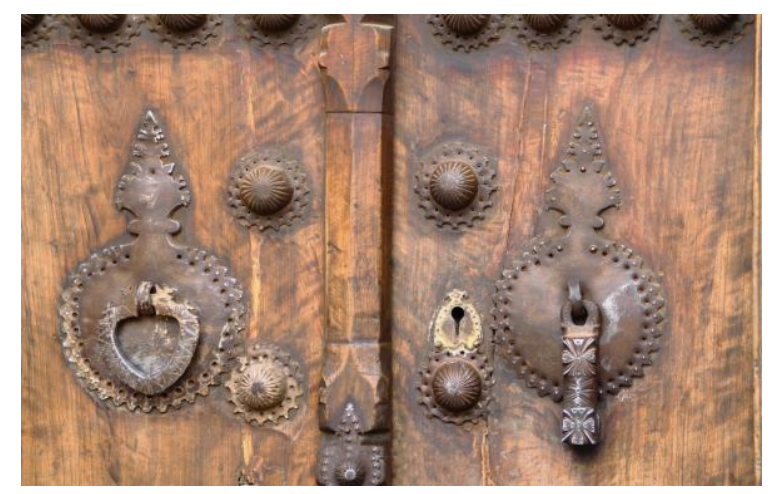

Resim 2. Kapı tokmağ (URL-5) 
Geleneksel Türk Evi’nde mekânların aydınlatılması ve dış dünya ile görsel ilişkinin sağlanması için oluşturulan pencereler, farklı biçimleri ve özellikleri ile evin cephe yüzeyinin tezyini niteliğine katkıda bulunurlar ve yapının genel görünümünde dinamik, zengin ve karakteristik bir mimari tasarım oluştururlar. "Evin, pencerelerle bir taraftan sokak ve diş dünyaya, diğer taraftan hayat ve eyvanla bahçeye açılmasına imkân veren planı, ona Türk Evi kimliğini kazandıran özel bir mimari yaklaşımdır.” (Cansever, 2002)

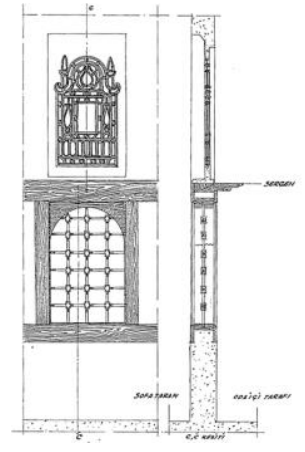

Şekil 4. Pencere detayı (Akok, 1957)

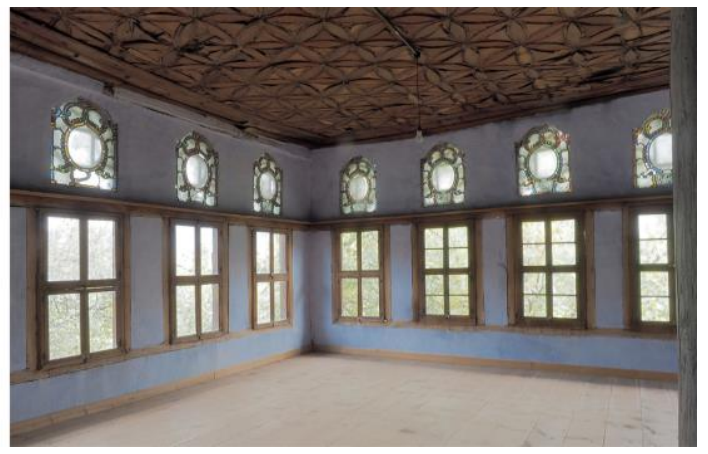

Resim 3. Geleneksel Türk Evi'nde pencere dizileri (URL-6)

Durağan bir mekân olan oda ile çevresi arasında güçlü ve dinamik ilişkiler kuran pencerelerin biçimlenişine ve kuruluşuna ilişkin bazı özellikler geliştirilmiştir. Zemin kattaki mekânların pencereleri olabildiğince küçük tutulmuştur. Üst katlardaki pencereler ise, ışık ve havalandırmadan olabildiğince fayda sağlanabilmesi ve daha iyi bir görüş alanının elde edilebilmesi için pencere duvarında çok sayıda kesintisiz açıklıklar oluşturulmuştur. Ayrıca, pencere önlerine, mahremiyetin korunmasını ve güvenliği sağlayan kafesler ve kapaklar tasarlanmıştır. Odaların ulaşılamayan ve kullanış açısından işlevi olmayan "soyutlanmış" üst örtüsünü oluşturan tavan bitkisel motifler ve geometrik formlar ile tezyin edilir. Bu üst örtüde yer alan vitraylı tepe pencereleri, mekânın aydınlatılmasına ve büyük bir özenle oluşturulan tavanın algılanması katkı sağlarlar.
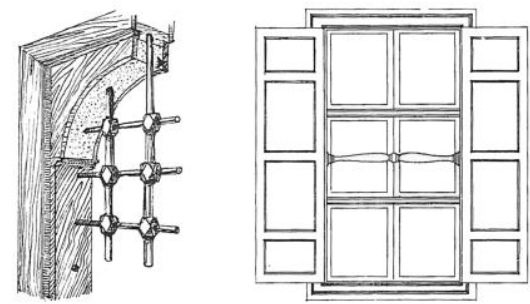

Şekil 5. Geleneksel Türk Evi'nde parmaklık ve kapaklar (Akok, 1957)

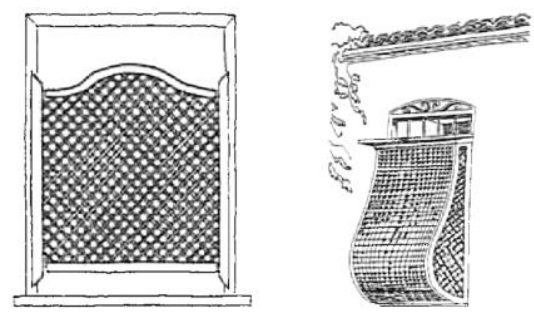

Şekil 6. Geleneksel Türk Evi'nde kafesler

(Kuban, 1995)

Yüklük duvarında, yıkanmak için oluşturulan gusülhane, yatak ve yorganların depolanması, saklanması ve korunması amacıyla yapılmış dolaplar, dekoratif amaçlı nişler ile ocak duvarında mekânın ısıtılması ve yemek pişirilmesi amacıyla tasarlanan ocakların işlevsel özelliklerinin yanı sıra görülen incelikli ahşap işçilikleri odanın görsel bir ifadeye bürünmesini sağlarlar.

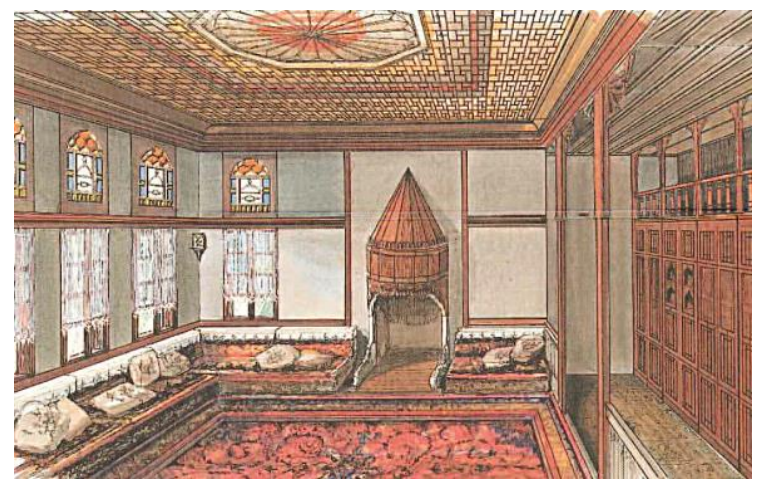

Şekil 7. Geleneksel Türk Evi'nde iç mekân kurgusu (Küçükerman, 1995)

Geleneksel Türk Evi’nde mekân kimliğine katkı sağlayan diğer bir yapısal eleman olan merdivenler, katları birbirlerine bağlayarak dolaşım sürekliliğini sağlayan ve tek kollu veya iki kollu gibi farklı biçimlerde olabilen mimari elemanlardır. Konutun iç mekânında, sofada ya da başka bir mekânda bulunabilen merdivenin, mekânda bulunduğu konumuna bağlı olarak plan tipi değişkenlik gösterebilmektedir. Dahası, etrafı galerilerle çevrelenip aydınlatılarak, incelikli ahşap işçilikleriyle mekânın kimliğini tanımlamaktadırlar. 

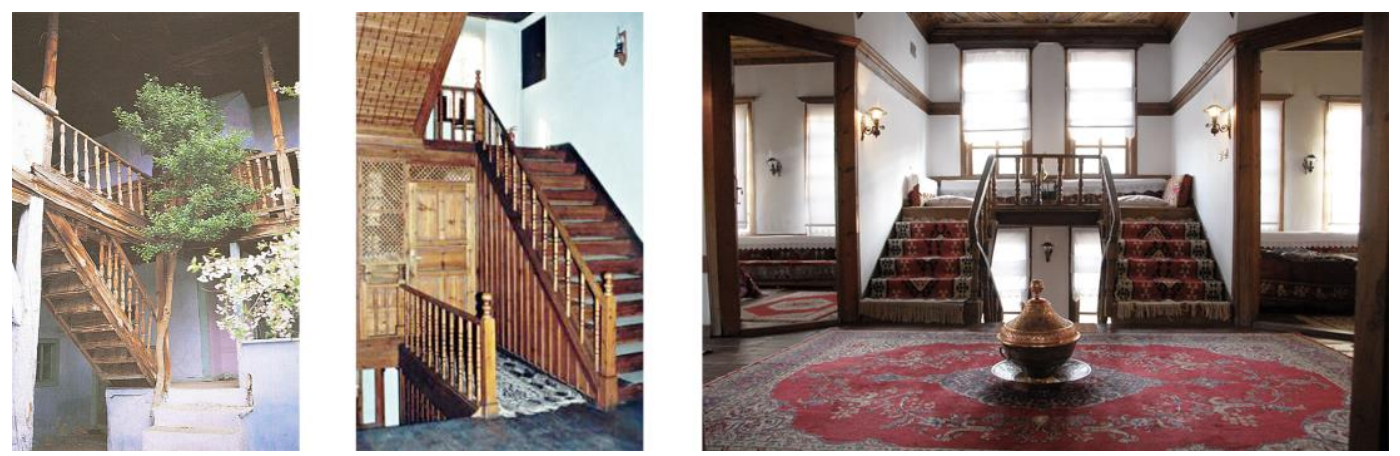

Resim 4. Geleneksel Türk Evi'nde merdiven örnekleri (Kuban 1995; URL-7; URL-8)

Çıkmalar, geleneksel Türk Evi'nin cephe görünümünü etkileyen ve konutun iç yaşamı ile dış dünya arasındaki görsel ilişkiyi kuran yapısal elemanlardır. Çıkmalar, "binaların şakuli satıhlardan ve yukarı kısımlarından, dışarı doğru ve altı boşta olarak ve taşımak üzere yapılan mimari kısımlardır." (Evren, 1959) Anadolu'nun bazı bölgelerinde "cumba" olarak anılan çıkmalar, iç mekândaki hayatın dış dünyaya açılmasını sağlayan mimari bir eleman gibi görünmesine rağmen bazı ihtiyaçlar ve zorunluluklar neticesinde meydana gelmişlerdir. Büyük kentlerde, dar ve sıkışık alanlarda üst katlardaki mekânlarda, çıkmalar ile genişletilerek yer kazanılır. Ayrıca, bu yapısal elemanlar ile yağmur ve güneşten de korunma sağlanır.
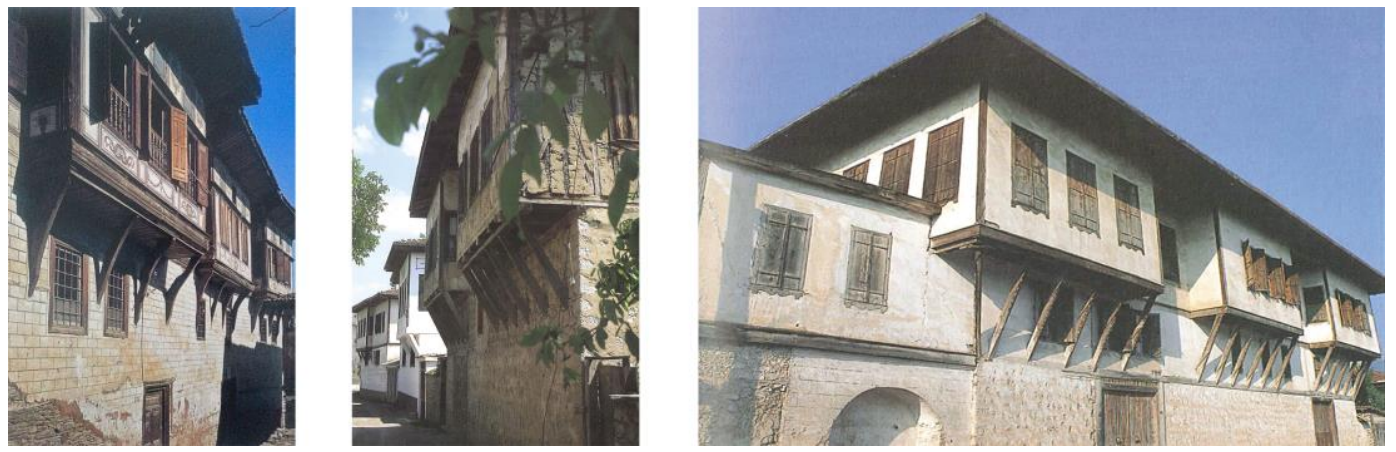

Resim 5. Geleneksel Türk Evi'nde çıma örnekleri (Günay, 2014; Kü̧̈ükerman, 1995)
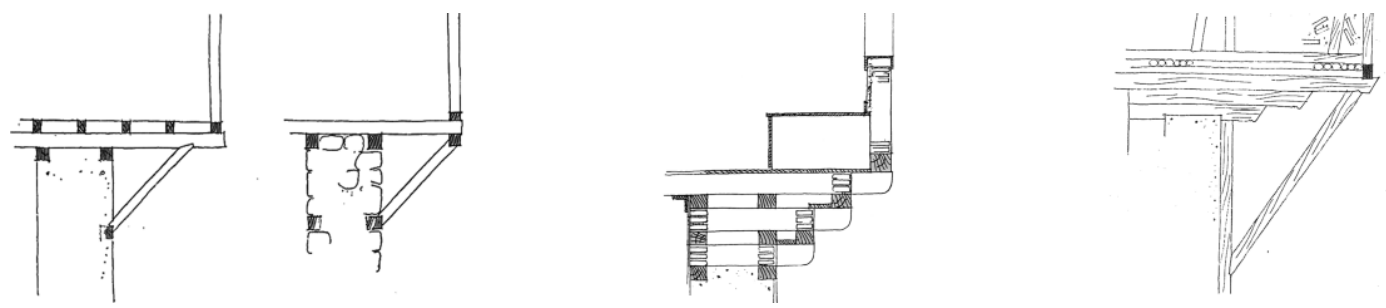

Şekil 8. Geleneksel Türk Evi’nde çıkma detayları (Evren, 1959)

"Çatı binayı tamamlayan, ona mimari hususiyetini kazandıran unsurların başlıcalarındandır. Şekil bakımından bu kadar mühim olan çatının bina bünyesindeki rolü ve konstrüksiyonu da o derece mühimdir. Çatı, bütün binayı hava tesirlerinden koruyan ve içinde barınılabilir bir hale getiren unsurdur." (Kafesçioğlu, 1954) Geleneksel Türk Evi’nin karmaşık planlarına karşlık basit çatı biçimleri (beşik, kırma, birleşik çatı) oluşturulmuştur. Geleneksel Türk Evi'nin mimari bütünlüğü içinde yer alan ve cephe düzeninde görsel bir etkiye sahip olan saçaklar ile hem çatı sağlamlaştırılır, hem de duvarlar hava koşullarından korunur.
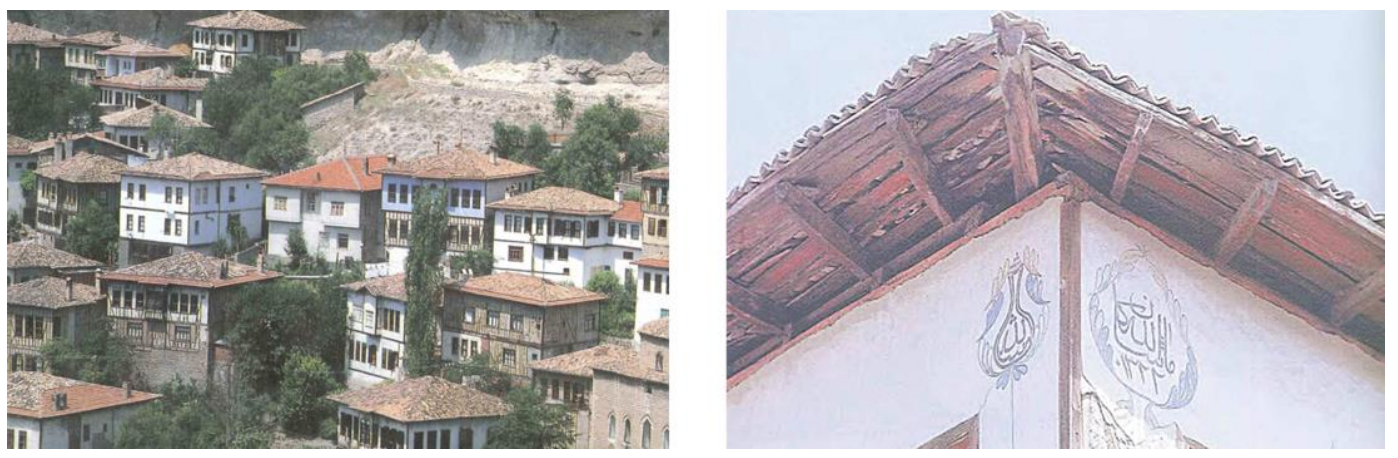

Resim 6. Geleneksel Türk Evi’nde çatılar ve saçak (Küçükerman, 1995; Kuban, 1995) 


\subsection{Geleneksel Japon Evi}

Kültürel değerlerini muhafaza etmeyi başarmış Japon toplumunun değer yargıları, inanç sistemleri ve ideolojileri ile şekillenen mimari tasarım yaklaşımlarının uygulandığı geleneksel Japon Evi, tarihsel süreç içerisinde önemli değişim ve gelişim aşamalarından geçerek oluşmuştur.

Japon tarihinin en erken tarihsel dönemi olan ve yerleşik yaşam düzenine geçildiği, kalıcı yerleşimlerin kurulduğu, avcılıktoplayıcılığın sürdürüldüğü Jomon dönemine (M.Ö. 14.000-300) ait yerleşim alanlarında "tateana-shiki jukyo" adı verilen dairesel veya dörtgen planlı barınaklar inşa edilmiştir. Heian dönemine (M.S. 794-1185) kadar konut mimarisinde önemli değişiklikler olmayıp imparatorluğun ve aristokrasi sınıfının doruk noktasına ulaştığı, her türlü sanat dalında gelişmeler yaşanmıştır. Ulusal bir mimari üslup geliştirildiği bu dönemde, ilk geleneksel Japon stili olarak nitelendirilen aristokratların ikamet ettiği "Shinden-zukuri", Japon mimarisinin temelini oluşturmaktadır.

Japon tarihine ait dönemlerin içinde en önemlisi olan Edo dönemi (M.S. 1603-1868), ekonomik büyümenin, sosyal düzende iyileşmelerin, yabancı politikalardan arınmanın, kültür ve sanatta yükselişin olduğu bir dönemdir. Japon mimarisinin en parlak zamanlarının yaşandığı bu dönemin sonlarına doğru, geleneksel Japon Evi’nin tam anlamıyla oluşmaya ve gelişmeye başladığı görülmektedir. Coğrafya, topografik oluşumlar, iklim özelliklerini içine alan doğal-fiziksel faktörler ile şekillenen ve toplumun yaşam biçiminin, inançların, geleneklerin dahil edildiği sosyo-kültürel faktörlerden beslenen yerel malzeme ve geleneksel yapım tekniğine dayalı yeni bir yapı geleneği geliştirilmiştir.

“Geleneksel Japon Evi, bölgelere, tarihsel, folklorik, iklimsel, malzemeyle ilgili, ekonomik, sosyal, politik vb. etkilere göre birtakım özgün biçimlerle gelişmiştir. Fakat zaman içinde ticaretin gelişmesi ve kültürel alışverişlerin sonucunda insanların hayatlarını bir düzene uydurmaya başlamasıyla plan tipleri de giderek aynı gelişmeyi göstermiştir.” (Yamamoto, 1989) Japonya'nın kırsal kesimlerinde büyük bir yayılım gösteren ve halkın kendi çabalarıyla inşa ettiği geleneksel karakterli çiftçi evleri "minka" ile şehir kültürünün gelişmesi ve tüccar sınıfının zenginleşmesiyle gelişen kasaba evi "machiya”, geleneksel Japon konut mimarisi açısından önemli ölçüde değere sahip olan vernaküler konut tiplerindendir.

Büyüklü küçüklü binlerce adadan oluşan ve coğrafi konumu bakımından izole bir bölgede yer alan Japonya, yüzyıllardır süregelen zengin ve köklü kültürünü itinayla korumaktadır. Japon toplumunda önemli bir yere sahip olan konut mimarisi, Japon kültürünün ve toplumun sosyal yapısının bir yansımasıdır. Japon toplumunun zengin kültürünü yansıtma bakımından büyük önem taşıyan, inanç ve kültürel değerler doğrultusunda şekillenen geleneksel Japon konut mimarisi yüzlerce yıldır varlığını sürdürmektedir.

Özgün niteliklere, kültürel zenginliğe ve tarihsel derinliğe sahip olan geleneksel Japon konut mimarisini basit ve tek bir tanımlamayla yorumlanamayacağı gibi, yerel mimarinin en yaygın özelliklerini dikkate alan bazı genel tanımlamalar yapmak mümkündür. "Bu genel tanımlamalar şunları içerir:

- Kullanıcının ikamet edeceği konutu kendi eliyle inşa etmesi

- Geleneksel teknolojilerin ve yöntemlerin kullanılması

- Çevresel verilerle güçlü ilişkilerin kurulması

- Malzemenin yerel kaynaklardan seçilmesi” (Linam, 1999)

Geleneksel Japon konut mimarisinin nesnel ve fiziksel özelliklerini içeren bu genel tanımlamanın yanında geleneksel Japon Evi’nin oluşumunda ve biçimlenişinde Japon kültürü ve toplumun yaşam biçimi ile Zen felsefesi ve inanç sistemleri en önemli etkenler olmuştur. Zen felsefesinin etkisi ile durgunluk, sakinlik ve huzurun hakim olduğu mekanlar oluşturulmuş; basitlik, doğallık, yalınlık ilkelerinin göz önünde bulundurulduğu çözümler üretilerek mekan organizasyonları kurgulanmıştır.

Sanat ve kültür hayatına ruh veren Zen-Budizmi mimaride de kendini açığa vuran bir Japon felsefesi olmuştur. Japon sanatlarının gelişiminde önemli katkıları olan Zen-Budizmi’nin etkilediği sanat dallarında bazı ortak ilkelerin takip edildiği görülmektedir. Bir sanat ve kültür akımı olan Zen-Budizmi ilkelerinin başlıcaları şunlardır:

- "Yalınlık (önceki dönemlerin karmaşıklığına karşı)

- İnsancillık (önceki anıtsal-toplumsal ölçeğe karşı)

- İçtenlik (önceki gösterişçiliğe karşı)

- Doğallık (önceki yapay zorlamalara ve moda akımlara karşı)

- Yaşl1lık-kusurluluk (önceki yenicilik ve yetkinlik çabalarına karş1)” (Güvenç, 2002)

Japon toplumunun yaşamı üzerinde büyük bir etki yaratan Zen-Budizmi’nin ilkeleri, sanatın her dalında ve gündelik yaşamın her anında uygulanmıştır.

Ayrıca, geleneksel Japon konutlarında sabit bir mekân kurgusuyla karşılaşılmaktadır. Tarım ürünlerinin işlendiği, depolandığı mekânların bulunduğu, yemeğin pişirildiği ve diğer günlük işlerin yapıldığı "doma" ile oturma, dinlenme, uyuma eylemlerinin gerçekleştiği “ima” geleneksel Japon Evi’nin oluşumunda önemli ölçüde etkili olan ve her kırsal kesim konutunda daima bulunan iki değişmez unsurdur. 


\section{Geleneksel Japon Evi'nin Yapısal Özellikleri}

Özgün nitelikleri, kültürel zenginlikleri ve tarihsel derinliği ile diğer vernaküler mimarilerden ayrılan geleneksel Japon konut mimarisi, fiziksel ve işlevsel oluşumları, yapısal, mekânsal özellikleri ve estetiksel zenginlikleri ile ön plana çıkmaktadır. Geleneksel Japon Evi'nde uygulanan tasarım yaklaşımları yapı geleneğinin karakteristik özelliklerinin biçimlenmesinde rol oynamaktadır. Geleneksel Japon konut geleneğinin başlıca özellikleri şöyle sıralanabilir:

- "Yapının, çevre ve bahçesiyle uyuşması

- Yapının cephesinde 'engawa' adı verilen üstü saçakla örtülü, yanları açık bir veranda yapılması

- Giriş kapısında 'genkan’ adı verilen bir antre bulunması

- İç bölmelerin ‘fusuma-shoji' diye bilinen hafif ahşap bölme ve kapılarla ayrılması

- Odalarla çatı boşluğunun ahşap bir tavan bölmesiyle birbirinden ayrılması

- Odalar arasında gömme dolap ve yerli yüklükler yapılması

- Oturma odasında 'tokonoma' adı verilen bir onur ve sanat başköşesi bulunması

- Tokonoma önüne, pencereden doğal ışık alan bir aile (yemek, oturma, çay) masası konması" (Güvenç, 2002)

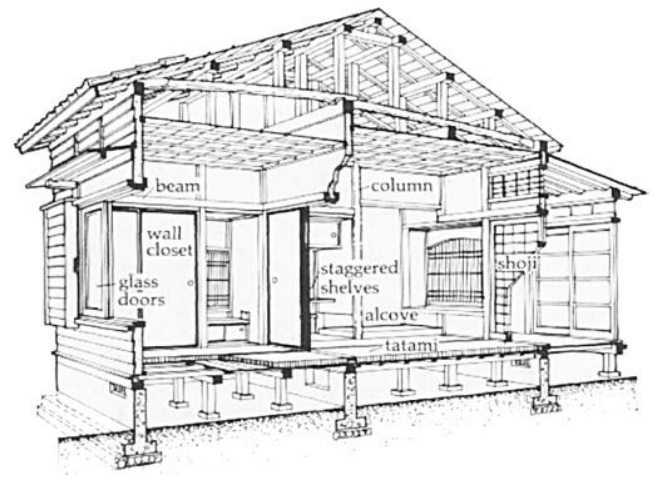

Şekil 9. Geleneksel Japon Evi'nin kurgusu (Yagi, 1986)

Geleneksel Japon Evi’ni oluşturan yapısal elemanlar, işlevsel özelliklerinin ötesinde mekân kurgusunun zenginleşmesinde ve mekânın özgün kimliğinin oluşmasında etkili olmaktadırlar. Mekânlar arasındaki erişim sürekliliğini, kullanım amacı doğrultusunda mekânların büyüyüp küçültülmesini, iç mekân ile doğa arasındaki dinamik ilişkileri sağlayan hareketli bölücüler "shoji ve fusuma", Japon konutuna özgün kimliğini kazandıran önemli birer yapı elemanlarıdır. Dikdörtgen ahşap çerçeve ve bu çerçevenin bir yönüne yapıştırılan yarı saydam kâğıttan (washi) oluşturulan shojinin üzerindeki motifler, gün içerisinde değişen güneş ışınları ile iç mekânda oluşan desenler, mekânı estetik açıdan zengin bir görünüme kavuşturur.

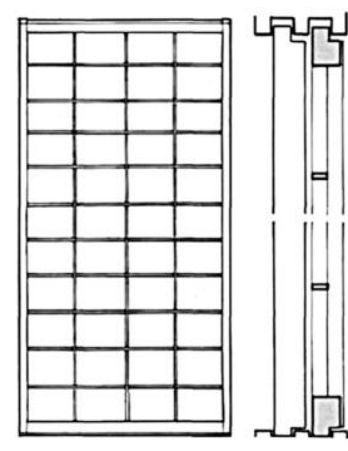

Şekil 10. Shoji detaylarl (Yagi, 1986)

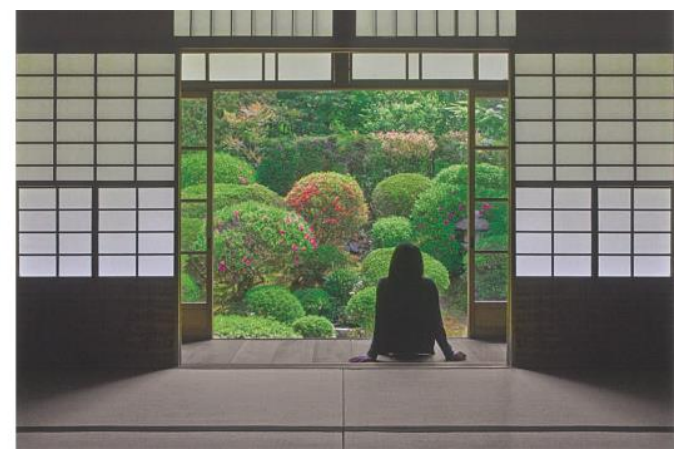

Resim 7. Geleneksel Japon Evi'nde shoji (Locher, 2010)

"Shojiye ek olarak, genel plana esneklik kazandıran başka hareketli bölücüler de bulunmaktadır. Fusuma, zemini tatami ile kaplı odalar (washitsu) arasında bulunan ahşap bir bölme aracıdır. Zaman zaman, özel törenlerde kaldırılarak geniş bir kabul alanı oluşturulur." (Yagi, 1986) Ahşap grid çerçeve her iki yüzünün ahşap panellerle kaplanmasıyla oluşturulan fusuma, iç-diş mekân sınırlandırılmasında kullanılır. Fusuma üzerlerine işlenen manzara veya mevsim değişimlerini yansıtan resimler ile mekânın tezyini niteliğine katkı sağlanır. Hatta Japon tarihinin erken dönemlerinde, özel törenlerin anısına davet edilen konuklar, fusumaya şiirler bırakırlardı. Fusumanın üst kısmında, iç mekân ile dış ortam veya iki oda arasında, mekânın aydınlatılması, havalandırılması amacıyla tasarlanan ve incelikli ahşap işçilikleriyle dikkat çeken "ranma" yer alır. 


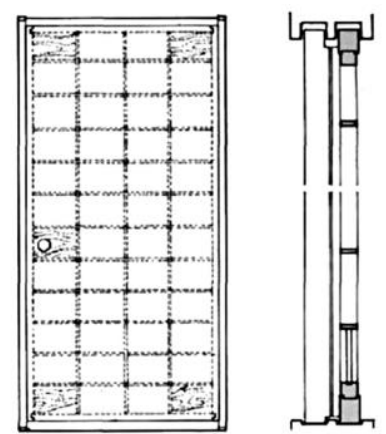

Şekil 11. Fusuma detayları (Yagi, 1986)

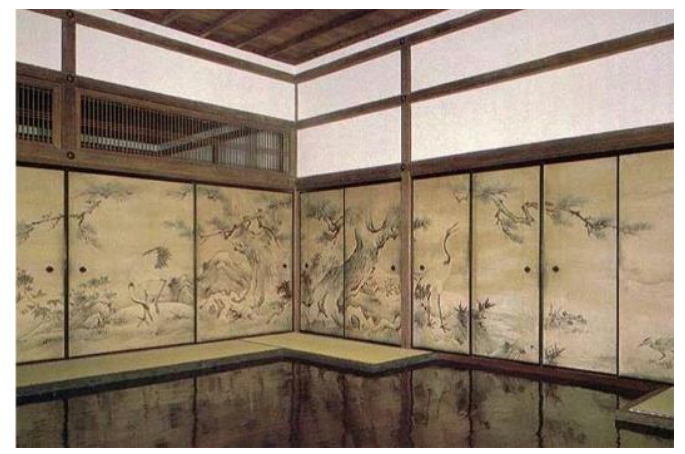

Resim 8. Geleneksel Japon Evi'nde fusuma (URL-9)

"Shoji ve fusuma adı verilen bu hareketli bölücüler ile mekânın fonksiyonu isteğe uygun olarak kolay ve hızlı bir şekilde değiştirilir. Yaz aylarında, bu bölücüler kaldırılarak havalandırma sağlanırken kış aylarında mekânın büyüklüğü azaltılarak 1sı kaybı kontrol altına alınır.” (Yagi, 1986) Geleneksel Japon Evi’nde, iç mekânı, dış ortamdan ayıran bir yapısal eleman bulunmayıp Japon kültüründeki doğa ile uyum esası doğrultusunda yap1, shoji ve fusuma gibi hafif bölücüler aracılığıyla doğa ile bütünleştirilir. Böylece, konutla doğa arasındaki sürekliliği sağlayan shoji ve fusuma, mekânı daha esnek ve kullanışlı hale getirirler.

Shoji ve fusumanın yanı sıra, kolayca kurulabilen ve hareket ettirilebilen çeşitli portatif bölücü tipleri bulunmaktadır. İki veya daha fazla panelin bir araya getirilmesiyle oluşturulan "byobu", bambu şeritlerinden oluşturulan katlanır perdeler "sudare" ve kendi başına, bağımsız olarak ayakta durabilen ve kolaylıkla taşınabilen "tsuitate" diğer bölücü elemanlardandır.

Geleneksel Japon Evi'nde iç mekân kurgusu, döşeme üzerine yerleştirilen tatami matlarının sayısı ve boyutları etkin rol oynamaktadır. Mekân planlamasında, mekânların büyüklüklerinin belirlenmesinde, tatami sayısının ölçü olarak kullanıldığı "jo” ile tataminin boyutlarının ölçü olarak kullanıldığı "tsubo" olmak üzere iki tür ölçüt kullanılır. Duvar vazifesi gören shoji ile fusumaların boyutları da tatami matlarının ölçülerine göre belirlenmektedir. "Dolayısıyla, bir mekânın tavanının yüksekliği, zemininde kullanılan tatami sayısı ile doğru orantılı olarak bulunur. Küçük odalar alçak tavanlara, büyük odalar ise taban alanına göre yüksek tavanlara sahiptir. Bu düzenleme konut tasarımında estetiğin önemli bir parçasıdır.” (Erdemir, 1993)

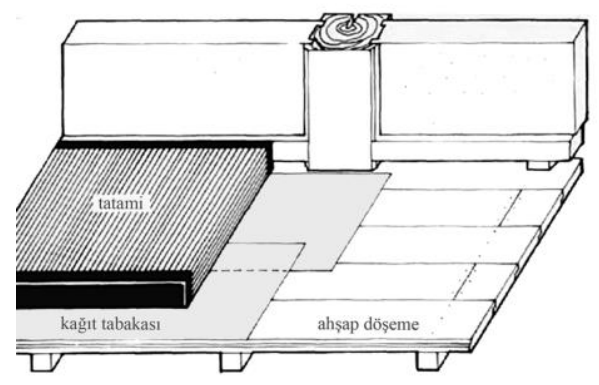

Şekil 12. Tatami matlarının kuruluşu (Yagi, 1986)

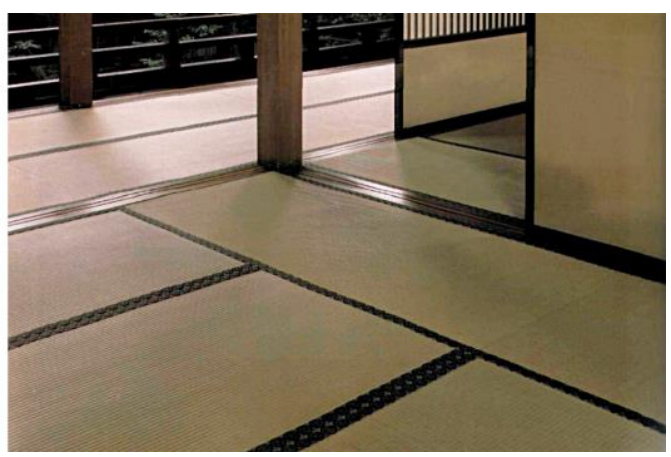

Resim 9. Geleneksel Japon Evi'nde tatami matlarl (Yagi, 1986)

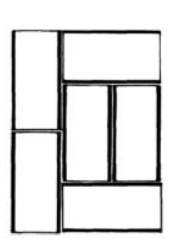

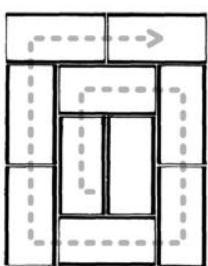

Şekil 13. Tatami matlarının bir araya getirilişinde uygulanan yöntem (Yagi, 1986)

Geleneksel Japon Evi, genellikle tek katlı olacak şekilde kurgulanmıştır. "Japonya'da köylerin, kasabaların ve şehirlerin tek katlı görünüşünü doğuran, doğayla insan arasındaki karşılıklı ilişkidir. En basit terimlerle ikinci kat yokumsanmıştır. İkinci katın yokumsanmasına bağlı olarak merdivende ve evin merdiven kesiminde mimari gerçekleşmenin tüm araçları yokumsanmıştır. Merdiven çok diktir ve böylelikle çok az bir döşeme alanı tutar. Ve yapılabildiği her yerde duvarlarla gizlenmiş veya bölmelerle çevrilmiştir. Merdivenlerin maddesel ve kaçınılmaz varlığı gizlenerek, dik yapılarak yokumsanmıştır.” (Ayverdi, 1972) 


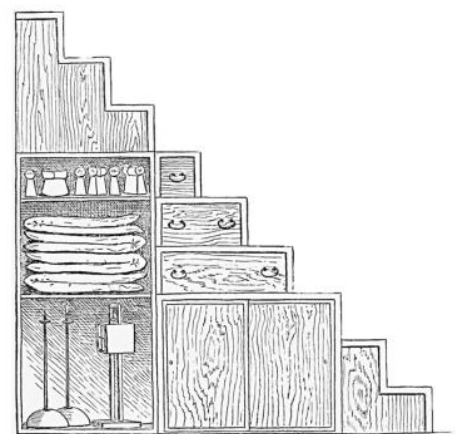

Sekil 14. Merdiven altınin fonksiyonel kullanımı (Morse, 1886)

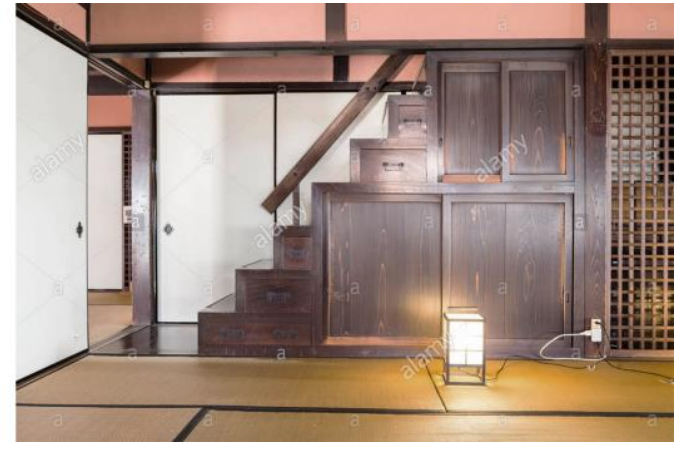

Resim 10. Geleneksel Japon Evi'nde merdiven örneği (URL-10)

Geleneksel Japon Evi'nde, iklim koşulları nedeniyle yağmur suyunun tahliyesi ve yoğun kar yükünün hafifletilmesi için genellikle kalın bir saz tabakası veya kiremitlerle örtülü dik çatılar oluşturulmuştur. Konutlarda uygulanan çatı biçimleri daima yalın tutulmuştur. Kirizuma-yane (beşik çatı), yosemune-yane (kırma çatı) ve irimoya-yane (birleşik çatı) konutlarda en sık görülen üst örtülerdir. Cephe düzeninde estetik bakımından öneme sahip olan saçaklar, evin duvarlarını hava koşullarından, iç mekanın yağmur ve güneşten korunmasını sağlar. Köşeleri yukarı doğru kıvrımlı olan saçaklar, engawanın (teras) aşırı yağışlardan etkilenmesini önler.

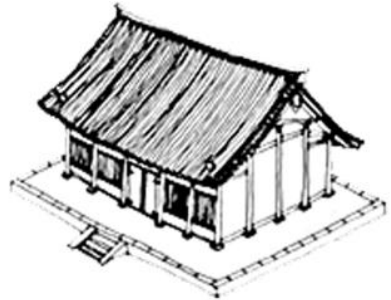

kirizuma-yane

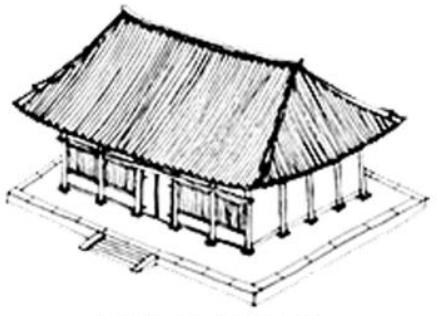

yosemune-yane

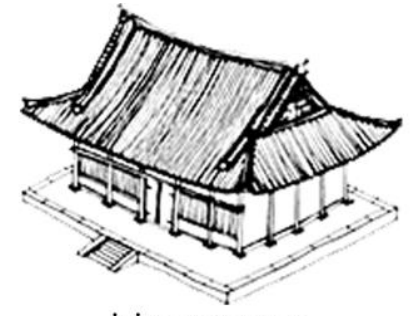

irimoya-yane

Şekil 15. Geleneksel Japon Evi'nde çatı türleri (URL-11)

\section{Geleneksel Türk Evi ile Geleneksel Japon Evi’nin Yapısal Açıdan Karşılaştırılmasıı}

Farklı coğrafyalarda konuşlanmış farklı iki toplumun geçmişte sürdükleri yaşam biçimleri ve bu dönemlerde edindikleri mimari tecrübeler, sonraki tarihsel süreç içerisinde inşa edilen konutların mekân kurgusuna yansıtılmıştır. Orta Asya'da göçebe yaşam sürdüren Türk toplumunun yaşama birimi olan göçer çadırı ile geleneksel Türk Evi’nin iç mekân kurgusu arasındaki ilişkinin benzeri, yerleşik yaşam düzeninin benimsendiği Jomon döneminde inşa edilen "tateana-shiki jukyo" adlı ilkel evlerin iç düzeni ile geleneksel Japon Evi mekan kurgusu arasındaki bağlantılarda görülebilmektedir.

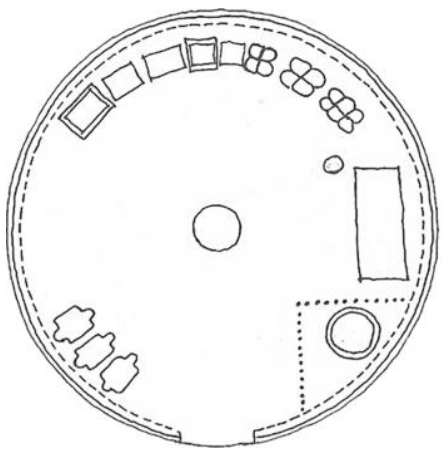

Şekil 16. Göçer çadırı (Küçükerman, 1995)

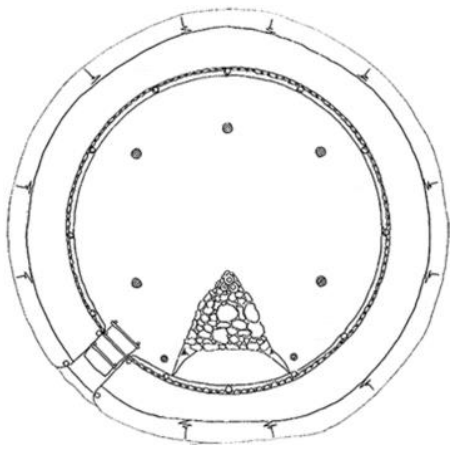

Şekil 17. Tateana-shiki jukyo (URL-12)

Konut formunun oluşumunda, coğrafya, topografik oluşumlar, iklim özellikleri, yapım tekniği, malzeme gibi faktörlerin önemli ölçüde etkisi bulunmaktadır. Çevre koşulları ile uyum içinde olmak ve doğaya uyum sağlamak, farklı coğrafyalarda üretilen her bir vernaküler mimarinin ortak karakteristik özelliklerinden olmuştur. Birbirinden farklı iklimsel özelliklere ve değişken topografik yapıya sahip coğrafyalarda yayılım gösteren geleneksel Türk Evi ile Japon Evi'nde bölgesel verilere bağlı olarak çevre şartları karşısında üstün nitelikler gösteren yerel yapı malzemeleri ile bölgeye özgü yapım teknikleri geliştirilmiş ve farklı konstrüksiyon çözümleri üretilmiştir. 
Geleneksel Türk Evi, ahşap çatkı sistemi, yatay ve düşey taşıyıcı elemanlarını destekleyen yardımcı strüktürler ve dolgu malzemeleri ile özgün nitelikli yapısal elemanları bir bütün halinde tasarlanarak kompleks bir görünüme kavuşmaktadır. Buna karşlık, geleneksel Japon Evi’nde, dikme-kiriş sistemini (torii) oluşturan yatay ve düşey taşıyıcılar ile hareketli bölücüler (shoji ve fusuma) yapının görünümüne daima hakim durumdadır. Hem Türk Evi hem de Japon Evi’nde uygulanan strüktür ve yapısal elemanlarda farklılıklar olmasına rağmen konutun yapısal nitelikleri cephe düzenlemelerini etkilemiştir. Her iki konut geleneğinin cephe görünümünde etkili olan yapısal unsurlar, planimetrik düzene de tümüyle yansımıştır.

Genellikle ahşap çatkı arası dolgu tekniği ile inşa edilen geleneksel Türk Evi'nde mekanların büyüklügü kullanılan ahşabın boyutuna göre değişim göstermiş ve buna bağlı olarak farklı konstrüksiyon çözümleri üretilmiştir. Japonya'nın çevre koşulları karşısında üstün nitelikler gösteren yerel yapı malzemeleri ile bölgeye özgü yapım teknikleri geliştirilmiş; dikme-kiriş sisteminde kullanılan ahşap türlerinin boyutları, istenilen ölçüde açıklığa sahip mekânlar üretmeyi mümkün kılmıştır. Buna bağlı olarak, konutlarda mekânların boyutları zemin kaplamasında kullanılan tatami matlarının ölçüleri ve sayısı belirlenmiştir.

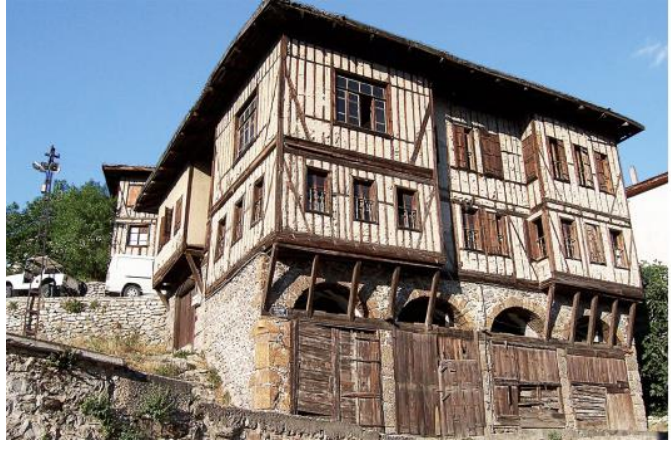

Resim 11. Geleneksel Türk Evi'nin genel görünüтӥ (URL-13)

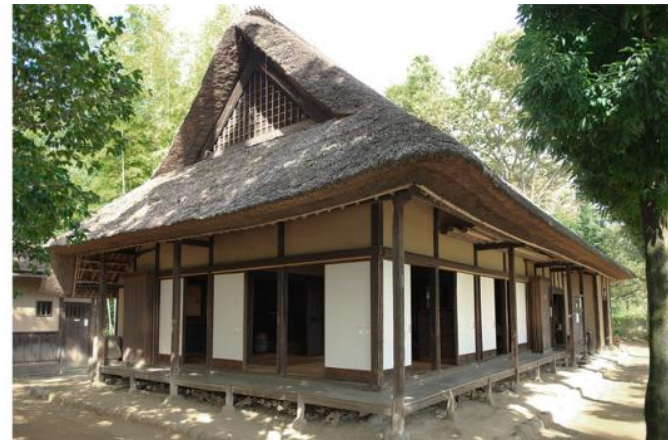

Resim 12. Geleneksel Japon Evi'nin genel görünümü (URL-14)

Özgün ahşap taşıyıcı strüktürüyle estetik ve zengin bir görünüme sahip olan geleneksel Türk Evi’nin duvarlarında pek çok amaca hizmet eden dolaplar, raflar, ocak ve pencere dizileri belli bir düzen içinde yerleştirilirler. Türk Evi'nde duvarlar, işlevsel özelliklerinin ötesinde mekân kurgusunda dekorasyonu tamamlayıcı unsurlardır. Tavanlarda ise, ailenin ekonomik durumuna bağlı olarak zengin özelliklere sahip detaylar oluşturulur. Türk toplumunun bağdaş kurarak oturması ve ibadetlerini zemin düzleminde yapmalarından dolayı, ahşap döşemenin üzeri halı veya kilimler ile kaplanır ve bu öğeler iç mekânın görünümünü zenginleştirir.

Geleneksel Japon Evi’nde, iç-dış mekân sınırlandırılmasını ve mekânların bölünmesini sağlayan sabit duvarlar olmayıp konut ile doğa arasındaki sürekliliği sağlayan hareketli bölücüler kullanılır. Bu hareketli bölücüler ile mekânlar daha esnek ve kullanışlı hale getirilirken, diğer taraftan da eşsiz süslemeleri ile estetik açıdan zengin mekânlar oluşturulur. Ancak, tinsel ve dinsel kaygılarla oluşturulan özelleşmiş mekânlarda (zashiki, chashitsu gibi) tokonoma, chigai-dana, tsuke-shoin gibi sembolik detaylara ayrılmış sabit duvarlar da bulunmaktadır. Japon Evi’nin özelleşmiş mekânların ve günlük yaşama ayrılan alanların üst örtüsünde, doğadan seçilen malzemelerden yapılmış tavan kaplanmaları kullanılırken doma, banyo, tuvalet gibi mekânlarda çatı strüktürü tamamen açık bırakılmıştır. Konutlarda döşeme, mekânın kullanımına uygun olarak, çalışma alanlarının zemini sıkıştırılmış topraktan yapılırken, yaşam alanlarının yükseltilmiş ahşap döşemenin üzeri tatami matları ile kaplanmaktadır.

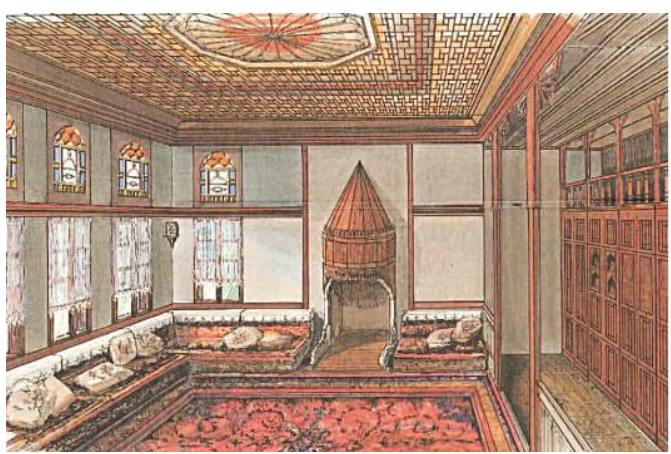

Şekil 18. Geleneksel Türk Evi'nde oda (Küçükerman, 1995)

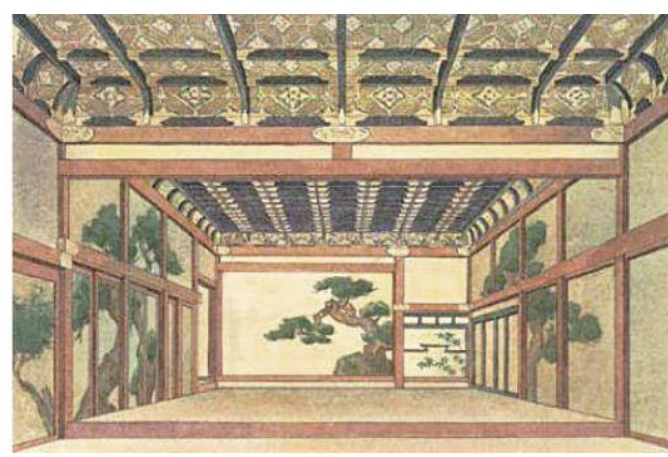

Şekil 19. Geleneksel Japon Evi'nde zashiki (Young ve Young, 2007)

İki konut tasarımının genel bütünlüğ̈̈ne bakıldığında, yapım tekniklerinde bir takım farklılıklar olmasına karşın toplumların yaşam biçimi, kültürel değerleri ve inanç sistemlerinin yapı bileşenlerine yansıtılması bakımından bazı noktalarda benzer özellikler taşıdıkları görülmektedir. Her iki konut geleneğinde, tavan, duvar ve döşeme ve çatı bütününden oluşan yapısal bileşenler ile kapı, pencere ve merdiven gibi diğer yardımcı bileşenler, hem işlevsel hem de dekoratif nitelikleri ile ön plana çıkmaktadırlar. 
Her iki yerel konut mimarisinde, mekânların kuruluşunda etkili olan yapısal, anlamsal ve işlevsel özellikler açısından bazı benzerlikler bulunmaktadır. Kültürel değerlere ve toplumsal özelliklere bağlı olarak oluşturulan geleneksel Türk Evi’nde yaşam katının plan şemasını oluşturan oda ve sofa, Türk ailesinin yaşam biçimine uygun olarak kurgulanmaktadır. Türk ailesinin mahremiyet esaslı yaşamına bağlı kalınarak tasarlanan odalar, kendi içinde gündelik yaşama dair ihtiyaçları (oturma, dinlenme, yemek yeme, uyuma gibi) karşllayabilecek özelliklere sahiptir. Toplumsal değerler, sosyo-kültürel yaşam ve zaruri ihtiyaçlar doğrultusunda şekillendirilerek esnek ve fonksiyonel mekân organizasyonunun ortaya konduğu geleneksel Japon Evi’nde, Türk Evi’nde olduğu gibi, aile üyelerinin toplandığı ve dinlenme, yeme-içme, uyuma gibi gereksinimlerin gerçekleştiği, ima adı verilen mekân bulunmaktadır. Bu bağlamda, her iki geleneksel konut tipi de, farklı işlevlerin bir arada gerçekleşebildiği, esnek olarak çözümlenmiş mekânsal kurguya sahip olmaları bakımından birbirleriyle benzerlik göstermektedir.
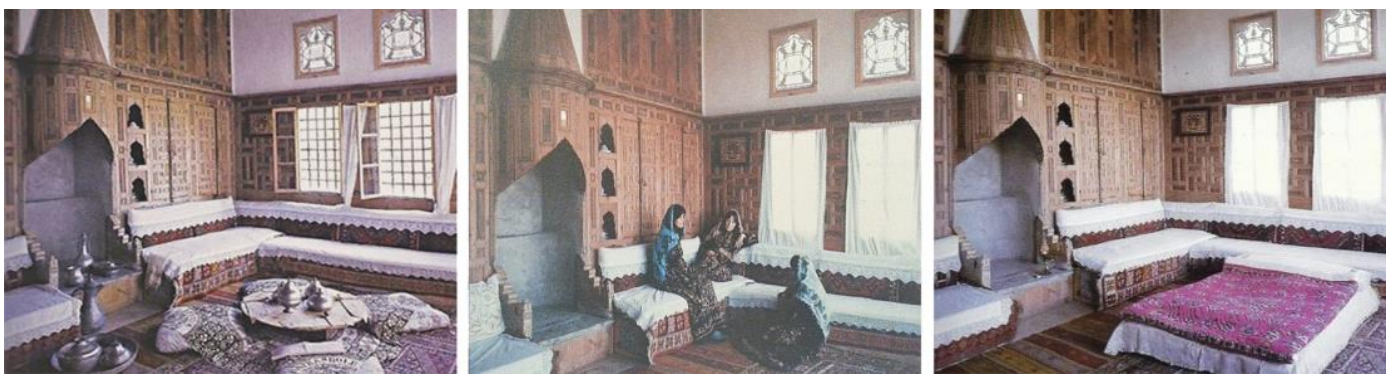

Resim 13. Geleneksel Türk Evi'nde mekânın işlevsel rolü (Günay, 1998)
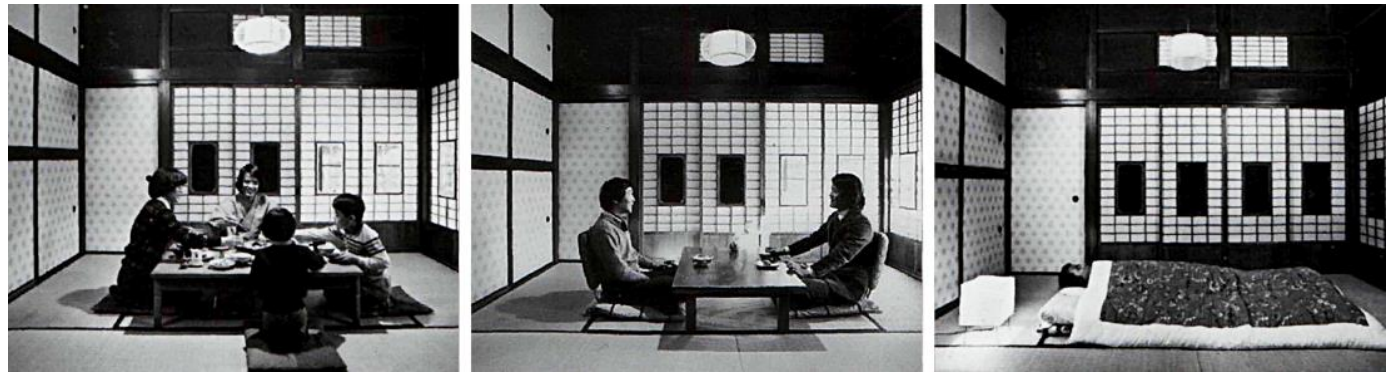

Resim 14. Geleneksel Japon Evi'nde esnek mekân kullanımı (Yagi, 1986)

Konut tasarımında, mekân kurgusuna katılan yapısal elemanlar, işlevsel niteliklerinin yanı sıra mekân ifadesinin zenginleşmesinde ve yapının özgün kimliğinin oluşmasında etkili olmaktadır. Geleneksel Türk Evi’nde kapı ve pencereler, farklı biçimleri ve özellikleri ile iç mekân düzenine ve yapının cephe görünümüne dinamik, zengin ve özgün nitelikler kazandırırlar. Yapıyı dış dünyadan ayırarak iç mekândaki yaşamın mahremiyetini koruyan kapılar, incelikli ahşap işçilikleri ve çeşitli estetik unsurları ile yapı bütününün görsel bir ifadeye kavuşması sağlanmaktadır. İslam dinine bağlı yaşayış biçimi göz önünde bulundurularak, yalın, gösterişsiz ve korunaklı biçimde tasarlanan pencereler, mekânların aydınlatılmasında ve iç-dış ilişkilerinin kurulmasında ve geliştirilmesinde önemli etkinliğe sahiptirler. Geleneksel Japon Evi’nde ise, kapı veya pencere olarak nitelendirilebilinecek sabit yapısal elemanlara rastlanmamakla birlikte, hem kapı ve pencere hem de duvar vazifesi gören hareketli bölücüler (shoji ve fusuma) bulunur. Hareketli bölücüler, farklı biçimleri ve süslemeleri ile konutun cephe ve iç mekân düzeninin tezyini niteliğine katkıda sağlarlar.

Ayrıca, her iki konut geleneğinde de, genellikle dekor niteliği taşıyan tepe pencerelerinin kullanımı ortak bir özelliktir. Geleneksel Türk Evi'ndeki vitraylı tepe pencereleri, mekânın aydınlatılmasına ve renklendirilmesine katkı sağlarken, geleneksel Japon Evi'ndeki ranma, dekoratif niteliğinin yanı sıra mekân içerisindeki havalandırmanın sağlanması ve mekânın aydınlatılması amaçlarıyla kullanilırlar.

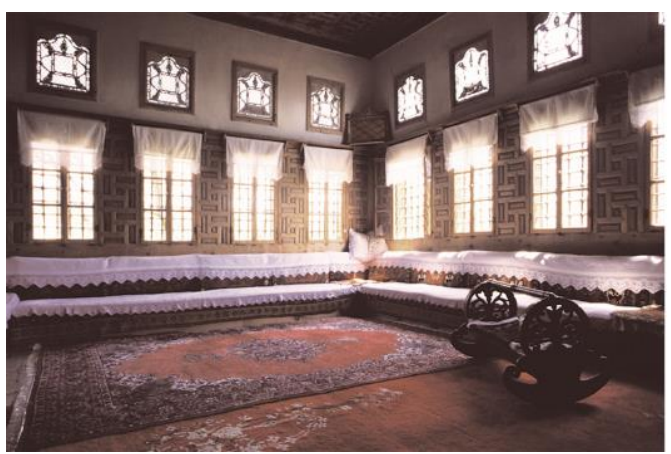

Resim 15. Geleneksel Türk Evi'nde pencere (URL-15)

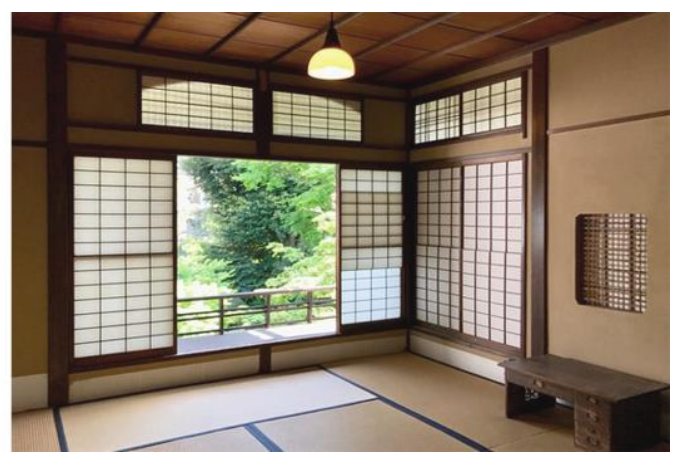

Resim 16. Geleneksel Japon Evi'nde shoji (URL-16) 
Özgün ahşap taşıyıcı strüktürüyle estetik ve zengin bir görünüme sahip olan geleneksel Türk Evi’nin duvarlarında pek çok amaca hizmet eden dolaplar, raflar, ocak ve pencere dizileri belli bir düzen içinde yerleştirilirler. Geleneksel Türk Evi'nde duvarlar, işlevsel özelliklerinin ötesinde mekân kurgusunda dekorasyonu tamamlayıcı unsurlardır. Tavanlarda ise, ailenin ekonomik durumuna bağ ${ }_{1}$ olarak zengin özelliklere sahip detaylar oluşturulur. Türk toplumunun bağdaş kurarak oturması ve ibadetlerini zemin düzleminde yapmalarından dolayı, ahşap döşemenin üzeri halı veya kilimler ile kaplanır ve bu öğeler iç mekânın görünümünü zenginleştirir.

Geleneksel Japon Evi’nde, iç-dış mekân sınırlandırılmasını ve mekânların bölünmesini sağlayan sabit duvarlar olmayıp konut ile doğa arasındaki sürekliliği sağlayan hareketli bölücüler kullanılır. Bu hareketli bölücüler ile mekânlar daha esnek ve kullanışlı hale getirilirken, diğer taraftan da eşsiz süslemeleri ile estetik açıdan zengin mekânlar oluşturulur. Ancak, tinsel ve dinsel kaygılarla oluşturulan özelleşmiş mekânlarda (zashiki, chashitsu gibi) tokonoma, chigai-dana, tsuke-shoin gibi sembolik detaylara ayrılmış sabit duvarlar da bulunmaktadır. Geleneksel Japon Evi'nin özelleşmiş mekânların ve günlük yaşama ayrılan alanların üst örtüsünde, doğadan seçilen malzemelerden yapılmış tavan kaplanmaları kullanılırken doma, banyo, tuvalet gibi mekânlarda çatı strüktürü tamamen açık bırakılmıştır. Konutlarda döşeme, mekânın kullanımına uygun olarak, çalışma alanlarının zemini sıkışııılmış topraktan yapılırken, yaşam alanlarının yükseltilmiş ahşap döşemenin üzeri tatami matları ile kaplanmaktadır.

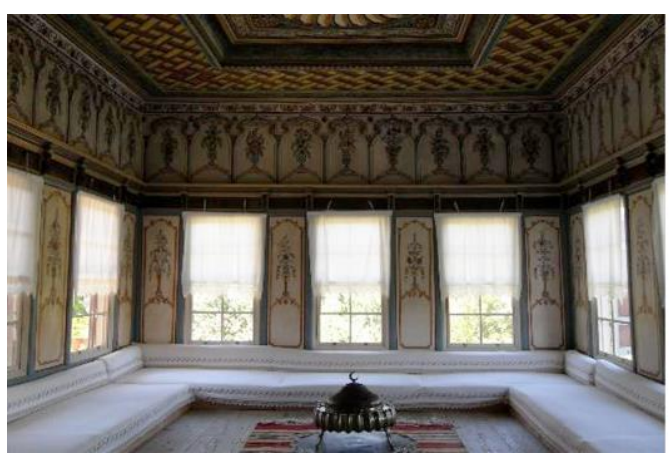

Resim 17. Geleneksel Türk Evi'nde yapısal bileşenler (URL-17)

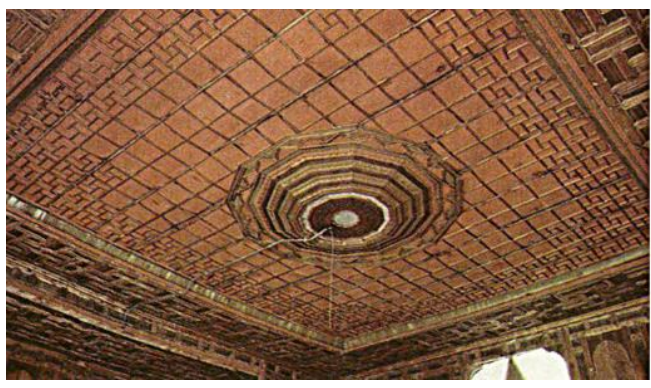

Resim 19. Geleneksel Türk Evi'nde üst örtü tezyinatı (Küçükerman, 1985)

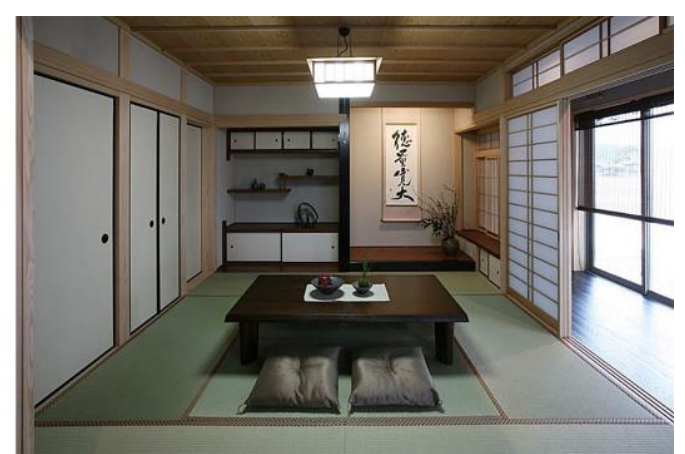

Resim 18. Geleneksel Japon Evi'nde yapısal bileşenler (URL-18)

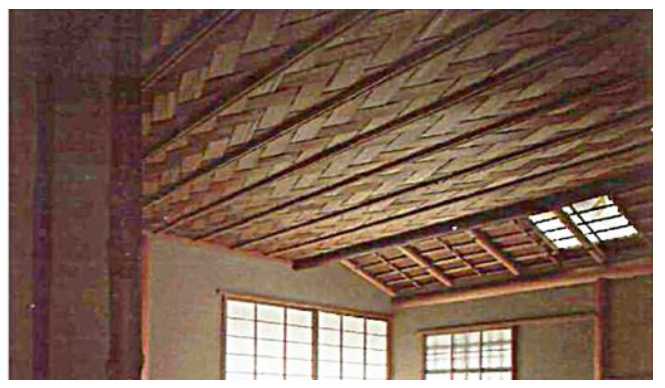

Resim 20. Geleneksel Japon Evi'nde tavan kaplamass (Yagi, 1986)

Geleneksel Türk Evi'nde, katları birbirlerine bağlayan ve katlar arası dolaşım sürekliliğini sağlayan merdivenler, farklı biçimleri ve incelikli ahşap iş̧̧ilikleriyle mekânın kimliğini tanımlarlar. Konutlarda önemli bir rolü olan merdivenlerin etrafı galerilerle çevrilir ve tüm merdiven doğal ışıkla aydınlatılarak mekân içindeki konumu vurgulanır. Geleneksel Japon Evi’nin genellikle tek katlı oluşuna bağlı olarak merdiven oluşturulmamıştır. Ancak, gerekli durumlarda oluşturulan merdivenler, duvarlarla gizlenerek veya bölmelerle çevrilerek maddesel varlıkları gizlenerek yokumsanmıştır.

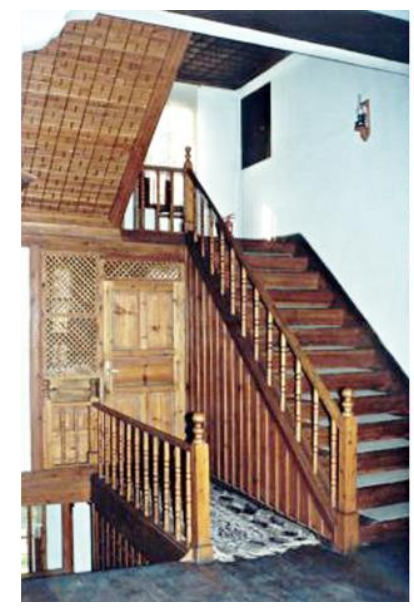

Resim 21. Geleneksel Türk Evi'nde merdiven (URL-19)

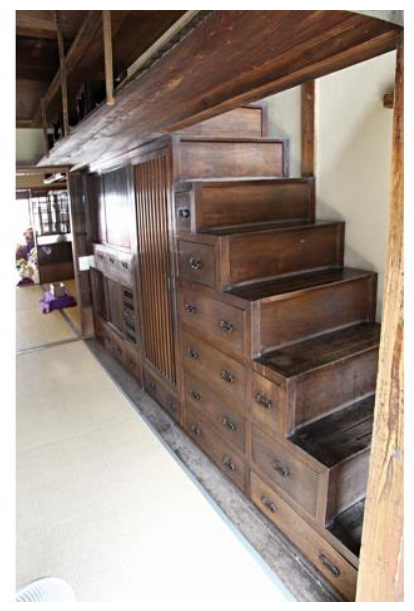

Resim 22. Geleneksel Japon Evi'nde merdiven (URL-20) 


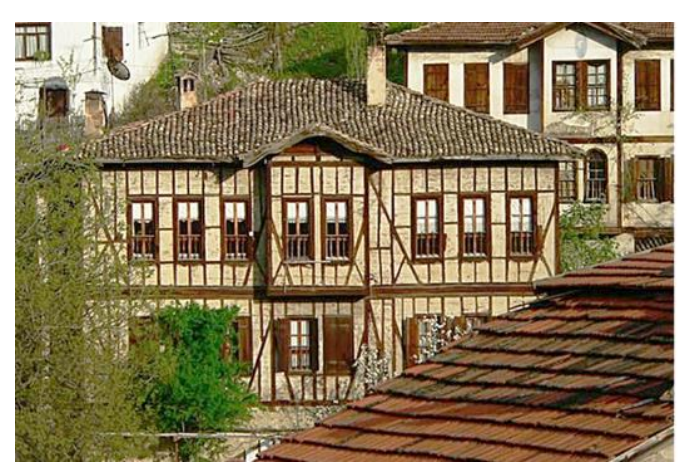

Resim 23. Geleneksel Türk Evi'nde çatı örtüsü (URL-21)

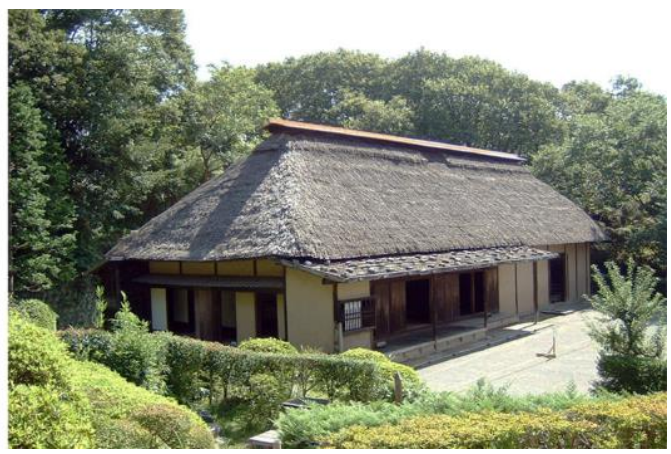

Resim 24. Geleneksel Japon Evi'nde çatı örtüsü (URL-22)

Her iki vernaküler konut mimarisinde, çatı örtüsü ve saçak uygulamaları birbirine benzer özellikler göstermektedir. Ahşap strüktürlü çatıların en önemli özelliği beşik ya da kırma ve onların birleşimlerinden meydana getirilen basit biçimlerle oluşturulmalarıdır. Dahası, gerek geleneksel Türk Evi gerekse geleneksel Japon Evi’nde, yapı bütünlüğü içinde yer alan geniş saçaklar, cephe görünümünde görsel bir etkiye sahiptir.

\section{Sonuç}

İnsanlık tarihinin başından günümüze dek, barınma, insanın en temel gereksinimleri arasında yer almıştır. İnsanoğlu, doğal çevre olaylarından ve çeşitli tehlikelerden korunmak için bölgesel verilerin ve zamanın teknolojik düzeyi elverdiği ölçüde barınma gereksinimini karşılayacak birtakım mekânlar oluşturmuştur. Toplumsal gelişme ile birlikte gelen yeni yaşam biçimi, değişen üretim ortamı, oluşan yeni ihtiyaçlar ve istekler doğrultusunda barınma kavramına bakış açısı değişmesiyle mimari üretimde farklılaşmalar meydana gelmiş ve fonksiyonel mekân organizasyonuna sahip konutlar geliştirilmiştir.

Tarihsel oluşum ve gelişim süreci içerisinde konut mimarisi, toplumsal kimlik, kültürel değerler, yaşam koşulları, tarihsel birikim gibi toplumsal dinamikler ile teknolojik düzey ve bölgesel özellikler ile bağlantılı olarak gelişerek özgün ve farklı kent dokuları oluşmasında etkili olmuştur. Kent dokusunu ve kimliğini oluşturan konut mimarisindeki farklılıklar, toplumun ideolojik tutumları, inanç sistemleri, kültürel değerleri, ekonomik yapısı, sosyal eğilimleri ile toplumun yaşanmışlıkları ve zaman içerisinde geçirdiği değişimler hakkında önemli ipuçları vermektedir. İnsanlık tarihinin başından günümüze kadar, uzun bir tarihsel oluşum ve gelişim sürecinden geçmiş olan geleneksel konut mimarisi, kültürel mirasın en önemli bileşenlerinden biri olarak varlığını sürdürmektedir.

Yoğun bir tarihi birikimden beslenen ve güçlü bir kültürel zenginliğin ürünü olan geleneksel Türk Evi ile geleneksel Japon Evi, birbirinden farklı iki topluma ait kültürel değerlerin bilinmesinin yanı sıra, geleneksel konut mimarisi ölçeğinde değerlendirmede, benzer noktalara temas edilmesi açısından oldukça çarpıcı bir tablo ortaya çıkarmaktadır. Birbirinden farklı coğrafyalarda üretilen iki geleneksel konut mimarisinin birbirinden ayrıldığı noktalar olmakla birlikte, toplumsal kimlik, kültürel değerler, inanç sistemi, bölgesel veriler ve tarihsel deneyimin mekâna yansıtılması, farklı işlevleri bir arada barındıran esnek mekân kurgusunun oluşturulması bakımından oldukça yakın benzer özellikler göstermektedir. Özgün yapım teknikleri ve yapısal özellikler, iç mekân organizasyonunda uygulanan tasarım yaklaşımları açısından birbirlerinden farklı özellikler taşıdıkları da görülmektedir.

\section{Kaynakça}

Akok, M. (1951). “Çorum’un Eski Evleri”, Arkitekt Dergisi, 237-238,171-189.

Akok, M. (1957). “Tokat Şehrinin Eski Evleri”, Ankara Üniversitesi Türk ve İslam Sanatları Tarihi Enstitüsü İlahiyat Fakültesi Yı1lık Araştırmalar Dergisi, 2, 129-151.

Ayverdi, A. (1972). Japonya Mimarlığı Mekanı: Özellikle İç Mekan Kuruluşuna Yaklaşım. İstanbul: İstanbul Teknik Üniversitesi Yayinlar1.

Bektaş, C. (2018). Türk Evi. İstanbul: Yapı Endüstri Merkezi Yayınları.

Bertram, C. (2012). Türk Evini Hayal Etmek Eve Dair Kolektif Düşler. İstanbul: İletişim Yayınları.

Boran, S., Yılmaz, D., Ürük, Z. F., Gökler, S. H. (2018). "Evaluation of Spatial Risks of Nursing Homes by Fuzzyy Risk Analysis Metod", 18. Uluslararası Üretim Araştırmaları Sempozyumu, Vienna Teknik Universitesi, Viyana, Avusturya.

Bossert, J. ve Meutes-Wilsing, A. (1997). Gündelik Yaşamda Zen. (çev. Seda Toksoy). İstanbul: Okyanus Yayıncılık.

Bostancığlu, E. (2002). Çatılar. İstanbul: İstanbul Kültür Üniversitesi Yayınları.

Bozkurt, S. G. (2013). “19.yy.da Osmanlı Konut Mimarisinde İç Mekan Kurgusunun Safranbolu Evleri Örneğinde İrdelenmesi”, İstanbul Üniversitesi Orman Fakültesi Dergisi, 62, 37-70.

Bozkurt, S. G. ve Altınçekiç, H. (2013). “Anadolu’da Geleneksel Konut ve Avluların Özellikleri ile Tarihsel Gelişiminin Safranbolu Evleri Örneğinde İrdelenmesi”, İstanbul Üniversitesi Orman Fakültesi Dergisi, 63, 69-91.

Cansever, T. (2002). Türk Evi’nin Mimarisi. Ankara: Yeni Türkiye Yayınları.

Cansever, T. (2009). İslam'da Şehir ve Mimari. İstanbul: Timaş Yayınları. 
Cansever, T. (2010). Osmanlı Şehri. İstanbul: Timaş Yayınları.

Cram, R. A. (1906). Impressions of Japanese Architecture and the Allied Arts. London: John Lane The Bodley Head.

De Mente, B. L. (2006). Elements of Japanese Design. New York: Tuttle Publishing.

Eldem, S. H. (1954). Türk Evi Plan Tipleri. İstanbul: İTÜ Mimarlık Fakültesi Yayınları.

Eldem, S. H. (1984). Türk Evi Osmanlı Dönemi. İstanbul: Türkiye Anıt Çevre Turizm Değerlerini Koruma Vakfı.

Erdemir, A. V. (2000). Genel Hatlarıyla Cha-No-Yu. Erciyes Üniversitesi Sosyal Bilimler Dergisi, 29, 105-115.

Erdemir, E. (1993). Culture-Space Relationship: Japanese Traditional Residential Interiors. Bilkent Üniversitesi, Güzel Sanatlar Enstitüsü, Yüksek Lisans Tezi, Ankara.

Evren, M. (1959). Türk Evinde Çıkma. İstanbul Teknik Üniversitesi, Mimarlık Fakültesi, Doçentlik Tezi, İstanbul.

Eyüce, A. (2005). Geleneksel Yapılar ve Mekanlar. İstanbul: Birsen Yayınevi.

Göğebakan, Y. (2015). "Karakteristik Bir Değer Olan Geleneksel Türk Evi'nin Oluşumunu Belirleyen Unsurlar ve Bu Evlerin Genel Özellikleri”, İnönü Üniversitesi Kültür Ve Sanat Dergisi, 1 (1), s.41-55.

Günay, R. (1989). Geleneksel Safranbolu Evleri ve Oluşumu. Ankara: Kültür Bakanlığı Yayınları.

Günay, R. (1998). Türk Ev Geleneği ve Safranbolu Evleri. İstanbul: Yapı Endüstri Merkezi Yayınları.

Günay, R. (2014). İstanbul'un Kaybolan Ahşap Konutları. İstanbul: Yapı Endüstri Merkezi Yayınları.

Güvenç, B. (2002). Japon Kültürü, İstanbul: Türkiye İş Bankası Kültür Yayınları.

Hasol, D. (2012). Ansiklopedik Mimarlık Sözlüğü. İstanbul: Yapı Endüstri Merkezi Yayınları.

Kafesçioğlu, R. (1954). Kuzey-Batı Anadolu'da Ahşap Ev Yapıları. İstanbul Teknik Üniversitesi, Mimarlık Fakültesi, Doçentlik Tezi, İstanbul.

Kakuzo, O. (2014) Çay ve Zen. (çev: Barış Acar). İstanbul: Maya Kitap.

Keskin, S. ve Yıldırım, K. (2016), "Geleneksel Kemaliye Evlerine Ait Kapıların İncelenmesi”, Sanat ve Tasarım Dergisi, sayı: 17, s. 119-137.

Koren, L. (2017). Sanatçılar, Tasarımcılar, Şair ve Filozoflar için Wabi-Sabi. (çev. Burcu Denizci). İstanbul: Sub Yayıları.

Köse, A. (2005). "Türkiye'de Geleneksel Kırsal Konut Planlarında Göçebe Türk Kültürü İzleri”, Afyon Kocatepe Üniversitesi Sosyal Bilimler Dergisi, 2, 158-191.

Kuban, D. (1976). Sanat Tarihimizin Sorunları. İstanbul: Çağdaş Yayınları.

Kuban, D. (1995). Türk "Hayat”lı Evi, İstanbul: Ziraat Bankası Yayınları.

Kuban, D. (2002). Mimarlık Kavramları. İstanbul: Yapı Endüstri Merkezi Yayınları.

Kuban, D. (2017). Türk Ahşap Konut Mimarisi 17. - 19. Yüzyıllar. İstanbul: Türkiye İş Bankası Kültür Yayınları.

Küçükerman, Ö. (1973). Anadolu'daki Geleneksel Türk Evinde Mekan Organizasyonu Açısından Odalar. İstanbul: Türkiye Turing ve Otomobil Kurumu Yayını.

Küçükerman, Ö. (1985). Kendi Mekanının Arayışı İçinde Türk Evi. İstanbul: Türkiye Turing ve Otomobil Kurumu Yayını.

Küçükerman, Ö. ve Güner, Ş. (1995). Türk Mirasında Türk Evleri. İstanbul: T.C. Kültür Bakanlığı Yayınları.

Linam, J. E. (1999). Machiya and Transition A Study of Developmental Vernacular Architecture. Virginia Polytechnic Institute and State University, Thesis Proposal, Virginia.

Matsushita, S. (2004). Comparative Study Of The Structure Of Traditional Timber Housing In Turkey And Japan. Orta Doğu Teknik Üniversitesi, Fen Bilimleri Enstitüsü, Yüksek Lisans Tezi, Ankara.

Morse, E. S. (1886). Japanese Homes and Their Surroundings. Boston: Ticknor and Company.

Naumann, R. (2007). Eski Anadolu Mimarlığı. Ankara: Türk Tarih Kurumu Yayınları.

Nishi, K. ve Hozumi, K. (1996). What is Japanese Architecture: A Survey of Traditional Japanese Architecture. Tokyo: Kodansha International Ltd.

Özdoğan, M. (1996). “Kulübeden Konuta: Mimarlıkta İlkler”, Tarihten Günümüze Anadolu'da Konut ve Yerleşme, Habitat II Konferans1, İstanbul.

Özel, Y. (2019). "Türk Evinde Sokağa Uzanan İç Mekanlar: Çıkmalar", 3. Uluslararası Uluslararası Sosyal ve Beşeri Bilimler Konferans1, Berlin, Almanya.

Özel, Y., Ürük, Z. F., Uzgören, G., Öztürk, T. (2018). “Mobilya ve Süs”, 2. Ulusal İç Mimari Tasarım Sempozyumu, Trabzon.

Öztürk, T., Ürük, Z. F., Özel, Y., Uzgören, G. (2018). "Mekansal Elverişlilik ve Fiziksel Çevre Kalitesi Bağlamında Mekânsal Kalite Analizi”, 2. Ulusal İç Mimari Tasarım Sempozyumu, Trabzon.

Rapoport, A. (1969). Human Form and Culture. USA: Prentice-Hall.

Roderick, J. (2008). Minka: My Farmhouse in Japan. New York: Princeton Architectural Press.

Sadler, A. L. (2009). Japanese Architecture: A Short History. New York: Tuttle Publishing.

Soetsu, Y. (1989). The Unknown Craftsman: A Japanese Insight into Beauty. Tokyo: Kodansha International Ltd.

Solak, S. G. (2017). "Mekan-Kimlik Etkileşimi: Kavramsal ve Kurumsal Bir Bakış", Manas Sosyal Araştırmalar Dergisi, 6 (1), s.1337.

Soshitsu, S. (1998). The Japanese Way of Tea: From its Origins in China to Sen Rikyu. Honolulu: University of Hawai'i Press.

Soysal. M. (1996). Tarihten Günümüze Anadolu'da Konut ve Yerleşmenin Öyküsü. İstanbul: Tarih Vakfı Yayınları.

Suzuki, S. (1992). Zen Zihni Başlangıç Zihnidir. (çev. Cem Şen). İstanbul: Dharma Yayınları.

Suzuki, D. T. (1997). Zen Budizm: D.T. Suzuki'den Seçme Yazılar. (çev. İlhan Güngören). İstanbul: Yol Yayınları.

Trevanian. (2004). Şibumi. (çev. Belkıs Çorakçı Dişbudak). İstanbul: E Yayınları.

Tuztaşı, U. (2010). İdeal Osmanlı Türk Evinin Anadolu Evlerinden Ayrıştırımında Biçimsel ve Bilimsel Açılamalar. Uluslararası Sosyal Araştırmalar Dergisi, 14, 497-510.

Tuztaşı, U. ve Aşkun, İ. Y. (2013). "Türk Evi İdealleştirmesinde Osmanlı Evi ve Anadolu Evi Kavramlarının Ortaklıklarına İlişkin İşlevsel Açıklamalar”, Bilig-Türk Dünyası Sosyal Bilimler Dergisi, 66, 279-296. 
Ürük, Z. F. (2016). "Medeniyetler İçinde Hamamın Gelişimi ve Kültürel Olarak Mekân Analizleri”, Akademik Sosyal Araştırmalar Dergisi- The Journal of Academic Social Science, 28, s. 185-209.

Ürük, Z. F., Yımaz, D. (2017) "Analysis of Spatial Flow and Determination Life Risks of People Living in Nursing Homes in İstanbul”, 17. Uluslararası Üretim Araştırmaları Sempozyumu, Vienna Teknik Üniversitesi, Viyana, Avusturya.

Vitruvius. (2005). Mimarlık Üzerine On Kitap. (çev. Suna Güven) İstanbul: Şevki Vanlı Mimarlık Vakfı Yayınları.

Yagi, K. (1986). A Japanese Touch for Your Home. Tokyo: Kodansha International Ltd.

Yamamoto, T. (1989). Geleneksel Türk ve Japon Evlerinin Mekansal ve Yapısal Açıdan Karşılaştırılması ve Koruma Yöntemlerinin İncelenmesi. Mimar Sinan Üniversitesi, Fen Bilimleri Enstitüsü, Yüksek Lisans Tezi, İstanbul.

Yamazaki, M. (2010). Japon Kültürü: Japonlar ve Bireycilik. (çev. Oğuz Baykara). İstanbul: Boğaziçi Üniversitesi Yayınevi.

Yoshida, T. (1956). The Japanese House and Garden. New York: Frederick A. Praeger.

Young, D. ve Young M. (2007). The Art of Japanese Architecture. New York: Tuttle Publishing.

Yürekli, F. ve Yürekli, H. (2007). Türk Evi Gözlemler-Yorumlar. İstanbul: Yapı Endüstri Merkezi Yayınları.

Watts, A. W. (1998). Zen Yolu: Zen Budizm'in İlkeleri. (çev. Sena Uğur). İstanbul: Şule Yayınları.

URL-1: https://www.timetoast.com/timelines/historia-de-la-arquitectura-i (Erişim Tarihi: 13.11.2018)

URL-2: http://tarihdeniz.blogspot.com/2009/12/cayonu-ilk-neolitik-yerlesimler.html (Erişim Tarihi: 15.11.2018)

URL-3: http://www.mustafacambaz.com/details.php?image_id=31459 (Erişim Tarihi: 26.11.2018)

URL-4: http://www.siverekhaber.com/unutulmaya-yuz-tutmus-tarihi-kapilar-p3-aid,6819.html\#galeri (Erişim Tarihi: 10.12.2018)

URL-5: http://minetozanlioglu.blogspot.com/2013/11/iran-gunlugum-11-isfahan.html (Erişim Tarihi: 10.12.2018)

URL-6: https://www.osmaneli.bel.tr/osmaneli-konaklari (Erişim Tarihi: 11.12.2018)

URL-7: http://www.sirtcantam.com.tr/emirhocazade-ahmet-beyler-evi.../ (Erişim Tarihi: 20.12.2018)

URL-8: https://www.dunyabulteni.net/kultur-sanat/osmanli-turk-evi-ozellikleri-h432420.html (Erişim Tarihi: 24.12.2018)

URL-9: http://artehistoriaestudios.blogspot.com/2018/12/capitulo-4-japon-moderno-temprano.html (Erişim Tarihi: 10.02.2019)

URL-10: https://www.alamy.es/foto-japon-izushi-izushi-shiryokan-museum-interior-gran-suelo-de-tatami-con-escalera-con-armariode-almacenamiento-incorporado-debajo-el-periodo-meiji-119566228.html (Erişim Tarihi: 14.03.2019)

URL-11: http://tsukushigata.webcrow.jp/others002.html (Erişim Tarihi: 15.02.2019)

URL-12: http://www.mahoron.fcp.or.jp/nenpou/nenpou2001_37.htm (Erişim Tarihi: 23.03.2019)

URL-13: http://www.wikiwand.com/tr/Osmanl\%C4\%B1_mimarisi (Erişim Tarihi: 25.03.2019)

URL-14: http://innersilence.jp/blog/?p=379 (Erişim Tarihi: 25.03.2019)

URL-15: https://sites.google.com/site/safranboluluyuz/eserler/evleri (Erişim Tarihi: 03.04.2019)

URL-16: https://interior-book.jp/112770 (Erişim Tarihi: 03.04.2019)

URL-17:https://www.tripadvisor.co.uk/LocationPhotoDirectLink-g311316-d547572-i43345760-Mehmet_Ali_Aga_Mansion-

Datca_Mugla_Province_Turkish_Aegean_Coast.html (Erişim Tarihi: 05.04.2019)

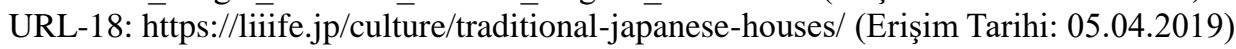

URL-19: http://www.sirtcantam.com.tr/emirhocazade-ahmet-beyler-evi.../ (Erişim Tarihi: 07.04.2019)

URL-20: https://gardenmirror.wordpress.com/ (Erişim Tarihi: 14.04.2019)

URL-21: http://www.mimdap.org/?p=114745 (Erişim Tarihi: 04.05.2019)

URL-22: http://touzainanboku.com/?p=1079 (Erişim Tarihi: 04.05.2019) 